

\section{DISCLAIMER}

This report was prepared as an account of work sponsored by an agency of the United States Government. Neither the United States Government nor any agency Thereof, nor any of their employees, makes any warranty, express or implied, or assumes any legal liability or responsibility for the accuracy, completeness, or usefulness of any information, apparatus, product, or process disclosed, or represents that its use would not infringe privately owned rights. Reference herein to any specific commercial product, process, or service by trade name, trademark, manufacturer, or otherwise does not necessarily constitute or imply its endorsement, recommendation, or favoring by the United States Government or any agency thereof. The views and opinions of authors expressed herein do not necessarily state or reflect those of the United States Government or any agency thereof. 


\section{DISCLAIMER}

Portions of this document may be illegible in electronic image products. Images are produced from the best available original document. 


\section{Printed in the United States of America. Available from}

National Technical Information Service

U.S. Uepartment of Commerce

5285 Port Royal Road, Springfield, Virginia 22161

Price: Printed Copy \$4.00; Microfiche $\$ 2.25$

This report was prepared as an account of work sponsored by the United States Government. Neither the United States nor the Energy Research and Development Administration/United States Nuclear Regulatory Commission, nor any of their employees, nor any of their contractors, subcontractors, or their employees, makes any warranty, express or implied, or assumes any legal liability or responsibility for the accuracy, completeness or usefulness of any information, apparatus, product or process disclosed, or represents that its use would not infringe privately owned rights. 
Distribution Category: UC-25

\title{
FRACTURE CHARACTERISTICS OF URANIUM ALLOYS BY SCANNING ELECTRON MICROSCOPY
}

\author{
J. W. Koger
}

Metallurgical Development Department

R. K. Bennett, Jr Laboratory Development Department Y-12 Development Division

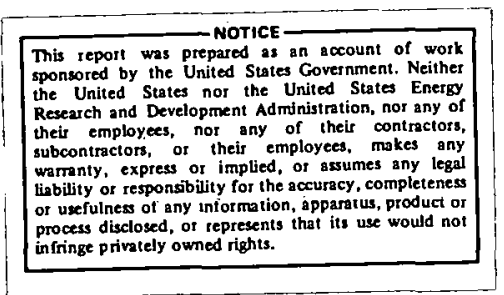

Uak Ridge $Y$-12 Plant

P. O. Box Y, Oak Ridge, Tennessee 37830

Prepared for the US Energy Research and Development Administration Under US Government Contraçt W-7405-eng-26 


\begin{abstract}
The fracture characteristics of uranium alloys were determined by scanning electron microscopy. The tracture mode of stress-corrosion cracking (SCC) of uranium-7.5 weight percent niobium-2.5 weight percent zirconium (Mulberry) alloy, uranium-niobium alloys, and uranium-molybdenum alloys in aqueous chloride solutions is intergranular. The SCC fracture surface of the Mulberry alloy is characterized by very clean and smooth grain facets. The tensile-overload fracture surfaces of these alloys are characteristically ductile dimple. Hydrogen-embrittlement failures of the uranium alloys are brittle and the fracture mode is transgranular. Fracture surfaces of the uranium- 0.75 weight percent titanium alloys are quasi cleavage.
\end{abstract}




\section{CONTENTS}

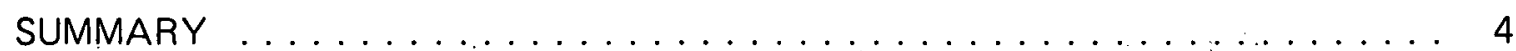

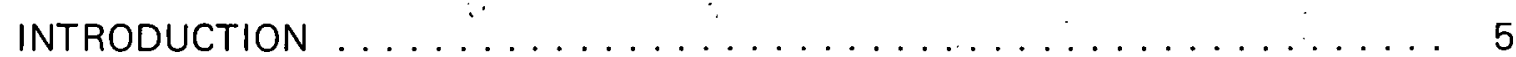

FRACTURE CHARACTERISTICS OF URANIUM ALLOYS $\ldots \ldots \ldots \ldots \ldots$

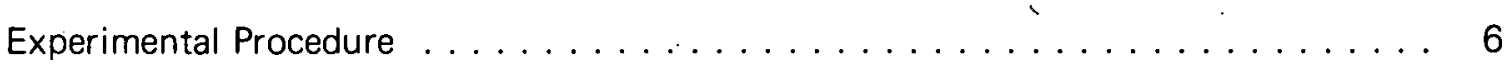

Fractography with the Scanning Electron Microscope . . . . . . . . . . . . . 6

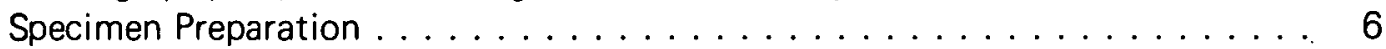

Scanning Electron Microscope Examination . . . . . . . . . . . . . 7

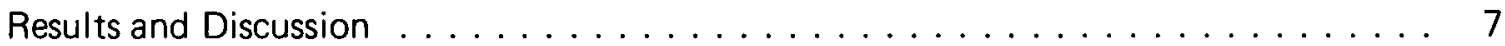

Uranium-7.5 Niobium-2.5 Zirconium Alloy (Mulberry) . . . . . . . . . . . . . . 7

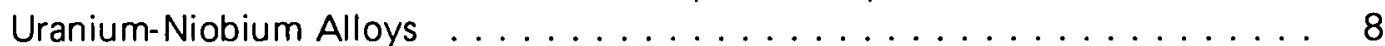

Uranium-Molybdenum Alloys ....................... 9

Uranium-Titanium Alloys . . . . . . . . . . . . . . . . . . 9

Conclusions . . . . . . . . . . . . . . . . . . . . . . . . . . 10

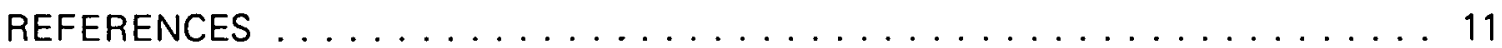

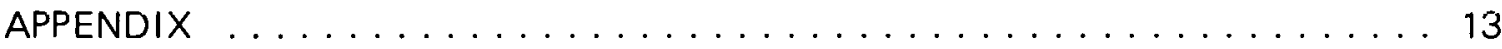

Micrographs of Alloy Specimens . . . . . . . . . . . . . . . 13 


\section{SUMMARY}

The purpose of this study was to contrast and compare various fracture surfaces of uranium alloys by using the scanning electron microscope (SEM). Aqueous chloride stress-corrosioncracking (SCC) failures, tensile-overload failures, and hydrogen-embrittlement failures were studied in uranium-7.5 weight percent niobium-2.5 weight percent zirconium alloy (Mulberry), uranium-niobium alloys, uranium-molybdenum alloys, and uranium-titanium alloys. The fracture mode of SCC was intergranular for all but the uranium-titanium alloys, and the fracture mode of tensile overload was ductile dimple. Hydrogen-embrittlement failures are brittle and the fracture mode is transgranular. Fracture surfaces of the uranium-titanium alloys are quasi cleavage. 


\section{INTRODUCTION}

Unalloyed uranium has rather poor mechanical properties and corrodes readily when exposed to the atmosphere. A desirable solution is to alloy the uranium with such elements as molybdenum and niobium which, in amounts over $4 \mathrm{wt} \%$, stabilize the high-temperature gamma phase at room temperature. Such binary alloys possess improved strength, ductility, and corrosion resistance.' In addition, their physical properties can be altered by heat treatment.

Ternary systems involving the three elements of note have also been considered and the uranium-7.5 niobium-2.5 zirconium (Mulberry) ternary alloy was found to have several improved properties, compared to uranium, and has been substituted for uranium on a production scale for certain applications.

For some applications, dilution of the uranium must be minimized. Studies have shown significant increases in the mechanical properties and oxidation resistance with very small additions $(<3 \mathrm{wt} \%$ ) of elements such as titanium, molybdenum, niobium, and zirconium. These alloys transtorm to a martensitic structure on water quenching from above $800^{\circ} \mathrm{C}$.

One objective of this report is to contrast and compare the fracture surfaces of various uranium-based alloys, like those mentioned, caused by SCC, hydrogen embrittlement, and a tensile-force overload. Saxton has an excellent review of the fracture behavior of several uranium alloys. (1) Characterization of the various fracture surfaces will prove helpful when failures occur in these alloys during service. Correlation of optical microstructures with these fracture surfaces is also of interest. The stress-corrosion failures occurred on exposure of stressed specimens to aqueous chloride solutions. Hydrogen-embrittlement specimens were made by charging hydrogen into the specimens at high temperature, followed by a rapid quench. The specimens were then subjected to a tensile test.

The work described in this report was performed at the Oak Ridge Y-12 Plant. (a)

(a) Operated by the Union Carbide Corporation's Nuclear Division for the US Energy Research and Development Administration. 


\section{FRACTURE CHARACTERISTICS OF URANIUM ALLOYS}

\section{EXPERIMENTAL PROCEDURE}

\section{Fractography with the Scanning Electron Microscope}

In general, there are four basic techniques used for examination and characterization of fracture morphology: (1) visual observation, (2) optical microscopy, (3) transmission electron microscopy (TEM), and (4) scanning electron microscopy (SEM), each of which can be documented by photography. The need for sufficient magnification to reveal the necessary microstructure for fractographic interpretation generally requires the use of either TEM or SEM. Since the introduction of commercially available SEM instruments in 1966 , this technique has been found to offer the simplest and quickest approach to fraclography. Discussions of all four methods, as well as the scope and usefulness of fractography in the characterization of metals, has been well documented in the literature. Une of the most inclusive treatments of the subject may be found in the Metals Handbook. (2)

\section{Specimen Preparation}

Three potential problems are encountered in the preparation of metal fracture specimens for examination by SEM: (1) cutting to a size compatible to fit the SEM specimen chamber; (2) protection from, or removal of, a destructive oxidation coating which hides the surface detail, and (3) cleaning extraneous material from the surface. Since the majority of the fractures discussed in this report were from specially prepared and experimentally fractured specimens, very few required cutting. When cutting was necessary, extreme care was taken to protect the tracture surface trom scrätches or other types ul disfiyur dliur..

Unlike the fractures of most steel alloys which destructively oxidize rapidly and require special protection (by such methods as immersion in an inert liquid or plastic coating), the uranium alloys investigated to date appear to torm a light protective oxide coat which dues not seem to obliterate the basic fractographic details. Thus, no surface-protection measures were used on the uranium alloy fracture surfaces, and no attempt was made to remove the oxide coat before the SEM analysis was performed.

The rough nature of a fracture surface makes it extremely susceptible to picking up and holding dirt, lint, fibers (from protective tissues), plastic particles (sample vials), oil, grease, and, particularly, "flnger grease" and/or tiriy bits of skin from handling. All of these contaminants must be cleaned from the surface before SEM examination to avoid artifacts. In addition to the obvious reasons for avoiding such artifacts, interaction of the electron beam with loosely attached particles can cause Incalized charging, resulting in distortion-not only in the field of view, but frequently in adjacent areas. Thus, all such contaminants must be removed by an effective cleaning technique. If possible, the cleaning process should not remove any corrosion products which were part of the fracture-initiation mechanism. Consequently, a gentle liquid ultrasonic treatment was utilized to clean the alloy surfaces. The first liquid used was a dilute aqueous detergent (a drop of a commercial dishwashing detergent in a beaker of water) and the second, acetone. Before placing the specimen in the SEM, an inspection of the surface was made by using a Stereozoom optical microscope in the 10X-to-30X magnification range. If surface contaminants were still 
present, longer ultrasonic times were tried and/or different organic solvents were used. In a few cases it was necessary to mechanically remove the contaminant (usually a fiber or piece of plastic trapped in a crevice) by brushing gently with a soft nylon brush with the specimen submerged in acetone. Regardless of the cleaning technique used, extreme care was exercised to avoid any damage to the fracture surface. For example, two specimens were never simultaneously treated ultrasonically in the same container because of the possibility that one specimen would scratch the other.

\section{Scanning Electron Microscope Examination}

The specimens were examined in a JEOL Model JSM-2 scanning electron microscope (SEM) equipped with a rapid-scan TV accessory and an ORTEC energy-dispersive $X$-ray identification unit. The entire fracture surface was surveyed at several magnifications using the TV-scan unit to check for such characteristics as uniformity, fracture modes, and corrosion products. Selected representative areas were chosen and micrographs were made using the SEM higher-resolution cathode-ray tubes, employing standard SEM techniques. The energy-dispersive $X$-ray unit was utilized to help identify inclusions and/or corrosion products.

\section{RESULTS AND DISCUSSION}

\section{Uranium-7.5 Niobium-2.5 Zirconium Alloy (Mulberry)}

Figure A-1 (Appendix) is an optical micrograph of an intergranular stress-corrosion crack in Mulberry that was vacuum water quenched from $800^{\circ} \mathrm{C}$ and aged at $150^{\circ} \mathrm{C}$ for one hour. The crack started from a pit. The intergranular character of the fracture is seen in a scanning electron micrograph, Figure A-2. Note the smooth grain facets and some secondary cracks at the grain boundaries. Figures A-3 through A-5 show Mulberry subjected to $0.35,0.70$, and $0.90 \%$ strain in an aqueous-chloride-containing solution. Failure times decreased with increasing strain. The grain facets of Figure A-3 are smoothest, perhaps since less strain was required before failure. More tear ridges are seen in Figure A-5 than in the others, as the specimen of Figure A-5 did undergo a higher strain. Magnani(3) and Zehr(4) have shown that, below a certain chloride ion level, an intergranular crack will not propagate in Mulberry, but transgranular cracking will occur and the path of the crack can be changed from intergranular to transgranular by lowering the chloride ion content.

The fracture surfaces shown in Figures $A-6$ and A-7 resulted from a fracture-toughness specimen exposed to $40 \%$ relative humidity air. The precracked area shows fatigue striations, a step-wise slip failure, and large dimples. The fracture surface shows fairly standard dimples. Figure A-8 is a tensile-overload area which looks much like Figure A-7. Increasing the hydrogen content of the alloy changed the fracture mode from ductile dimple to a mixed ductile dimple and dimpled intergranular.

Partially recrystallized Mulberry is much more resistant to aqueous-chloride-induced stresscorrosion cracking (SCC) than fully recrystallized Mulberry. (5) The fracture surface of a partially recrystallized SCC specimen shows both ductile dimple and intergranular characteristics (Figure A-9). The presence of ductile areas indicates that the sample failed by tensile overload of the reduced surface area which resulted from the SCC. The sample would not fail by SCC alone. 
Certain additions have been made to Mulberry to improve its mechanical properties and to affect its grain size. Figures $\mathrm{A}-10$ and $\mathrm{A}-11$ are stress-corrosion fracture surfaces of Mulberry with an addition of $0.25 \mathrm{wt} \%$ chromium (in Figure A-10) and $0.75 \mathrm{wt} \%$ germanium (in Figure A-11). (The specimens were strained 1\%.) Note the smooth grain facets and the precipitates in both cases. X-ray identification techniques showed that the precipitates were chromium rich in Figure A-10 and germanium rich in Figure A-11.

Fracture surfaces of the three "modified" Mulberry alloys were compared. These specimens were also strained 1\%. Figure A-12 is an SEM of the fracture surface of a specimen of U-6.5 Nb-1.5 $\mathrm{Zr}$ alloy. The surface is intergranular, with secondary cracks and corrosion product noted on the surface.

Figure A-13 shows the fracture surface of a U-\%.5 Nb-2.5 Hf alloy specimen. The failure is intergranular, but the grain facets are not quite as smooth as those of "normal" Mulberry. Secondary cracks and precipitates are visible, along with some evidence of ductility. Figure A-14 is an SEM of the fracture surface of a U-8.5 Nb-1.5 Zr alloy specimen. Again, smooth faceted grains are the rule.

Mulberry, loaded with $100 \mathrm{ppm}$ of hydrogen, fails in tension in a ductile manner (Figure A-15. Circle 2). Comparison of the intergranular failure under stress-corrosion conditions and the ductile behavior when loaded with hydrogen indicate that hydrogen embrittlement and SCC involve two totally different mechanisms.

\section{Uranium-Niobium Alloys}

Figure A-16 is a view of a tensile overload tracture surtace of uranlum-4 nloblum (U-4 INU)

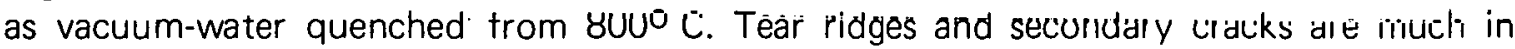
evidence, with no obvious dimples. The failure mode is ductile transgranular. The specimen of Figure A-17 failed under a strain of $1 \%$ in an aqueous chloride solution. The fallure is primarily intergranular. Corrosion products are present.

Uranium-6 niobium (U-6 Nb) is a gamma-quenched alloy which can be age hardened.(6) Figure A-18 is a typical optical micrograph of an intergranular stress-corrosion crack in vacuum-water quenched U-6 Nb unaged or aged below $300^{\circ} \mathrm{C}$. The fracture surface of the crack is seen in Figure A-19. Corrosion products are also noted. The grain facets are not as smooth as those in Mulberry. Atter aging at $300^{\circ} \mathrm{C}$, the strength of U-6 Nb is greatly increased and the ductility and stress-corrosion resistance is greatly decreased. Figure A-20 shows the tensile-overload fracture of the $300^{\circ} \mathrm{C}$-aged U-6 Nb alloy. The fracture is primarily ductile dimple. Figure A-21 shows a SCC fracture of the $300^{\circ} \mathrm{C}$-aged U-6 Nb alloy. The failure is primarily intergranular, with some quasi-cleavage regions.

After aging at $600^{\circ} \mathrm{C}$, the alloy consists of two phases, is quite strong, and has reasonable ductility. Because one of the phases is high in uranium, the alloy is quite susceptible to general corrosion attack. An optical micrograph of a pearlitic two-phase structure is seen in Figure A-22. Figure A-23 shows the stress-corrosion fracture surface of the $600^{\circ} \mathrm{C}$-aged U-6 $\mathrm{Nb}$ alloy. The black phase was brittle; and, because of the eutectoid structure, the fracture mode is difficult to define. 
The SCC fracture surface of a vacuum-water quenched U-6 Nb. alloy with $1000-p p m$ zirconium is seen in Figure A-24. Little effect of the zirconium addition was noted. The failure is intergranular, with considerable secondary cracking.

The tensile fracture surfaces of uranium-8.5 niobium (U-8.5 Nb) at three different hydrogen levels: $0 \mathrm{ppm}$ (Circle 1k, $12 \mathrm{ppm}$ (Circle 2), and $27 \mathrm{ppm}$ (Circle 3). are shown in Figure A-25. Above $15 \mathrm{ppm}$ hydrogen, the fracture is quite brittle and transgranular.

Figure A-26 shows the tensile-overload fracture of the uranium-10 niobium (U-10 Nb) alloy. The fracture is characteristically ductile dimple. Figure A-27 shows a SCC fracture of the $\mathrm{U}-10 \mathrm{Nb}$ alloy. Note that the failure is primarily intergranular. Corrosion product and secondary cracking are also noted. The tensile-overload fracture surface for U-10 Nb containing $0 \mathrm{ppm}$ (Circle 1), $9 \mathrm{ppm}$ (Circle 2), and $30 \mathrm{ppm}$ (Circle 3) hydrogen is given in Figure A-28. The fracture is brittle, transgranular, and features small cleavage steps.

\section{Uranium-Molybdenum Alloys}

A stress-corrosion fracture surface of the as-quenched uranium-6 molybdenum (U-6 Mo) alloy is shown in Figure A-29. The failure mode is predominantly intergranular, and secondary cracks are seen. Figure A-30 shows the interface between both a stress-corrosion fracture surface and an overload surface. The overload surface of a specimen aged at $400^{\circ} \mathrm{C}$ has ductile-dimple characteristics, while the stress-corrosion surface is intergranular with some ductile areas. Figure A-31 is a micrograph of the stress-corrosion fracture surface of a specimen aged at $550^{\circ} \mathrm{C}$. The fracture surface is intergranular and a second phase is seen at the grain boundaries.

Figure A-32 reveals the tensile-overload surface of as-quenched uranium- 8 molybdenum (U-8 Mo) alloy. The fracture is predominantly ductile dimple. Figure A-33 is a view of the stress-corrosion fracture surface of the same alloy and it is primarily intergranular. Figure A-34 is the micrograph of the stress-corrosion fracture surface of U-8 Mo that was overaged at $550^{\circ} \mathrm{C}$. The fracture path is primarily intergranular, with some evidence of fracture of the second-phase particles.

The failure mode of uranium-10 molybdenum (U-10 Mo) alloy with no hydrogen in the overload tensile tests was dimpled rupture. Additional amounts of hydrogen changed the appearance of the fracture surface to that of a brittle transgranular failure (Figure A-35). The surface shown in Circle 2 was from an alloy that contained 6 ppm hydrogen, while the material of Circle 3 contained 8 ppm hydrogen.

\section{Uranium-Titanium Alloys}

An optical micrograph of the uranium-0.75 titanium (U-0.75 Ti) alloy, aged at $400^{\circ} \mathrm{C}$, is seen in Figure A-36. The microstructure is characterized by lenticular martensite and vestiges of the original grains. Figure A-37 shows the SCC surface of the alloy. Fracture occurred by shearing of the martensite lenticules, and the fracture appears as quasi cleavage following the martensitic phase. Johnson, et al, (7) have shown that this fracture mode does not change with the changing test condition. Figure A-38 shows the SCC surface of a U-0.75 Ti-0.25 V alloy. The surface is somewhat different, due to different martensite phase 
morphology. The surface resulting from tensile overload has a ductile appearance, as seen in Figure A-39.

\section{CONCLUSIONS}

Several conclusions can be stated because of this study:

1. The SCC fracture surface (from exposure to chloride solutions) of U-7.5 Nb-2.5 Zr alloy (Mulberry) shows very clean and smooth grain facets. The fracture mode is intergranular.

2. The tensile-overload fracture surfaces of Mulberry, the uranium-niobium alloys, and the uranium-molybdenum alloys are characteristically ductile dimple.

3. Hydrogen-embrittlement failures are brittle and the fracture mode is transgranular.

4. SCC fracture surfaces (chloride induced) of uranium-niobium alloys and uraniummolybdenum alloys are intergranular, but not as clean as those of Mulberry.

5. Fracture surfaces of the uranium -0.75 titanium alloy are quasi cleavage. 


\section{REFERENCES}

(1) Saxton, H. J.; Fracture of Uranium Alloys, SLL-74-5215; Sandia Laboratory, Livermore California (19?4).

(2) Metals Handbook, Vol 9, 8th Edition; Fractography and an Atlas of Fractographs; American Society for Metals, Metals Park, Ohio 44073.

(3) Magnani, N. J.; "Stress Corrosion Cracking of Mulberry", Corrosion, 26, p 406 (1970).

(4) Zehr, S. W.; "A Study of the Intergranular Cracking of U-7.5 Wt \% Nb-2.5 Wt $\% \mathrm{Zr}$ (Mulberry) Alloy in Aqueous Chloride Solution", Corrosion, 28, p 196 (1972).

(5) Koger, J. W.; Variables Which Influence the Stress-Corrosion Cracking of Uranium-7.5 Niobium-2.5 Zirconium Alloy, Y-1965; Union Carbide Corporation-Nuclear Division, Oak Ridge Y-12 Plant, Oak Ridge, Tennessee; January 28, 1974.

(6) Koger, J.W., Ammons, A. M., and Ferguson, J. E.; Effect of Aging on the General Corrosion and Stress-Corrosion Cracking of Uranium-6 Wt \% Niobium Alloy, Y-1999; Union Carbide Corporation-Nuclear Division, Oak Ridge Y-12 Plant, Oak Ridge, Tennessee; November 26, 1975.

(7) Johnson, H. R., Dini, J.W., and Zehr, S. W.; On the Embrittlement of Uranium and Uranium-0.8 Titanium Alloy by Hydrogen and Water, SLL-73-5300; Sandia Laboratories, Livermore, California (1973). 


\section{THIS PAGE}

\section{WAS INTENTIONALLY LEFT BLANK}


APPENDIX

MICROGRAPHS OF ALLOY SPECIMENS 


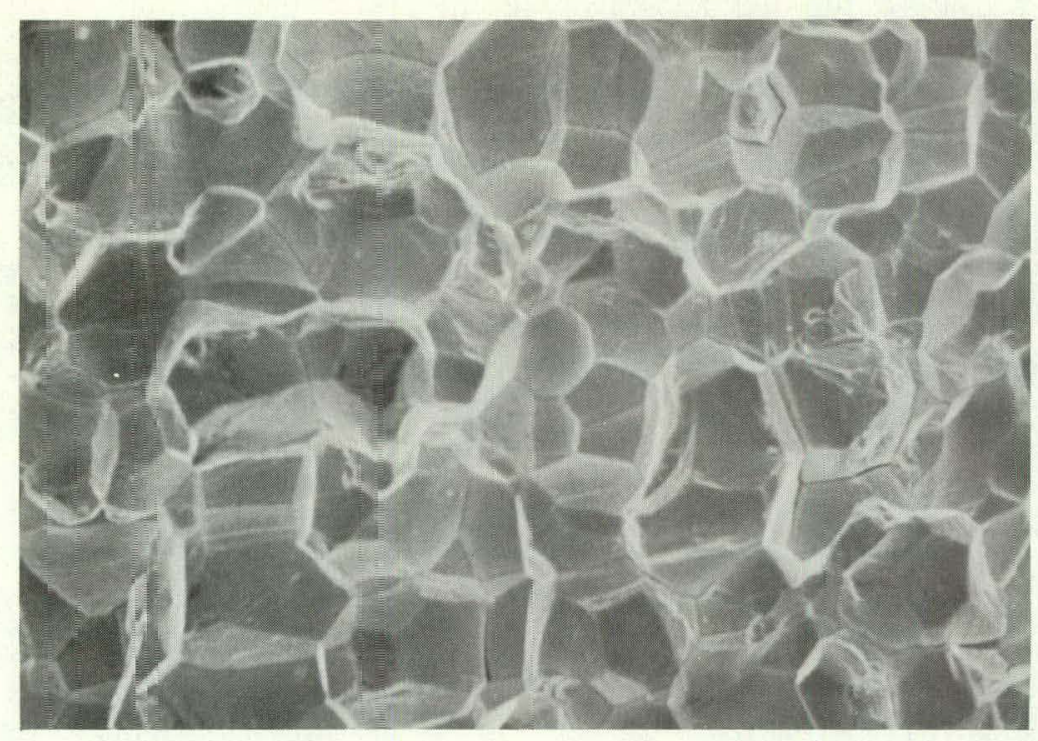

(a) At $1000 x$.

SM-43665

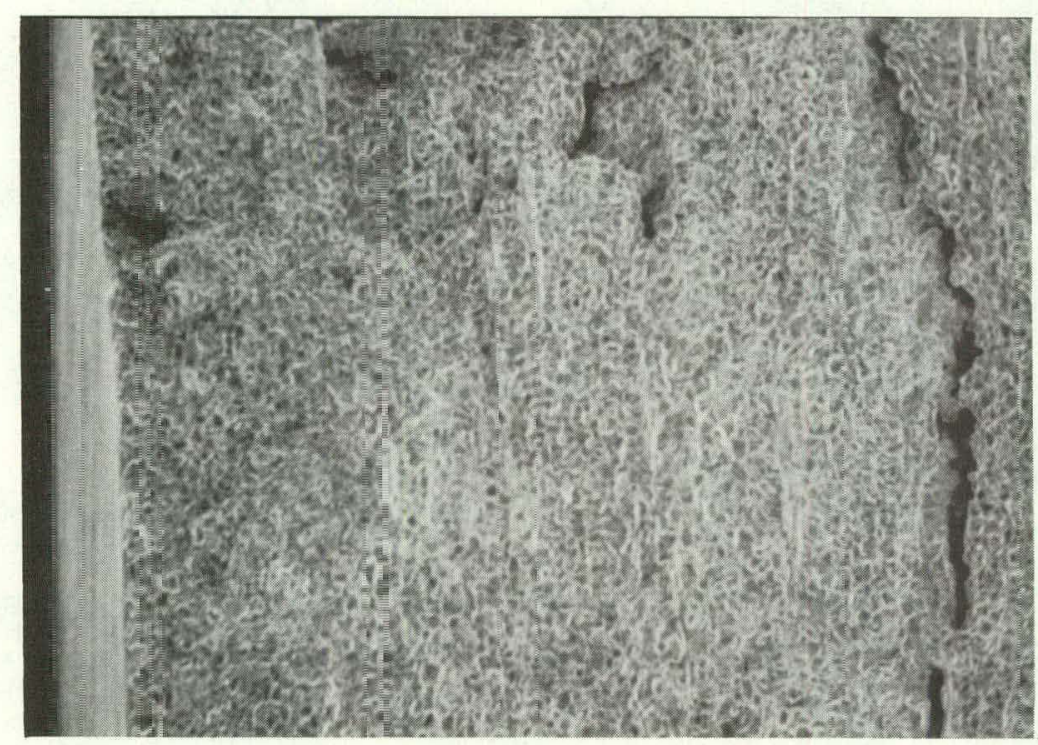

(c) At $100 x$

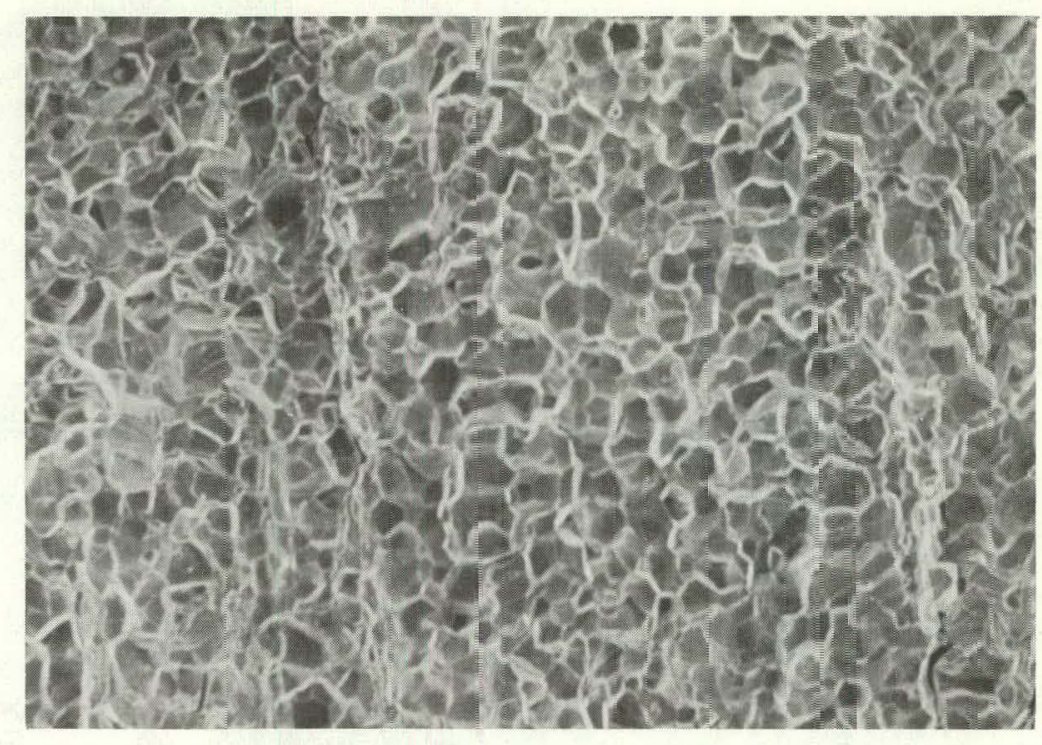

(b) At $300 x$.

SM-43666

Figure A-1. OPTICAL MICROGRAPH OF A STRESS-CORROSION CRACK IN URANIUM-7.5 WEIGHT PERCENT NIOBIUM-2.5 WEIGHT PERCENT ZIRCONIUM (MULBERRY). 


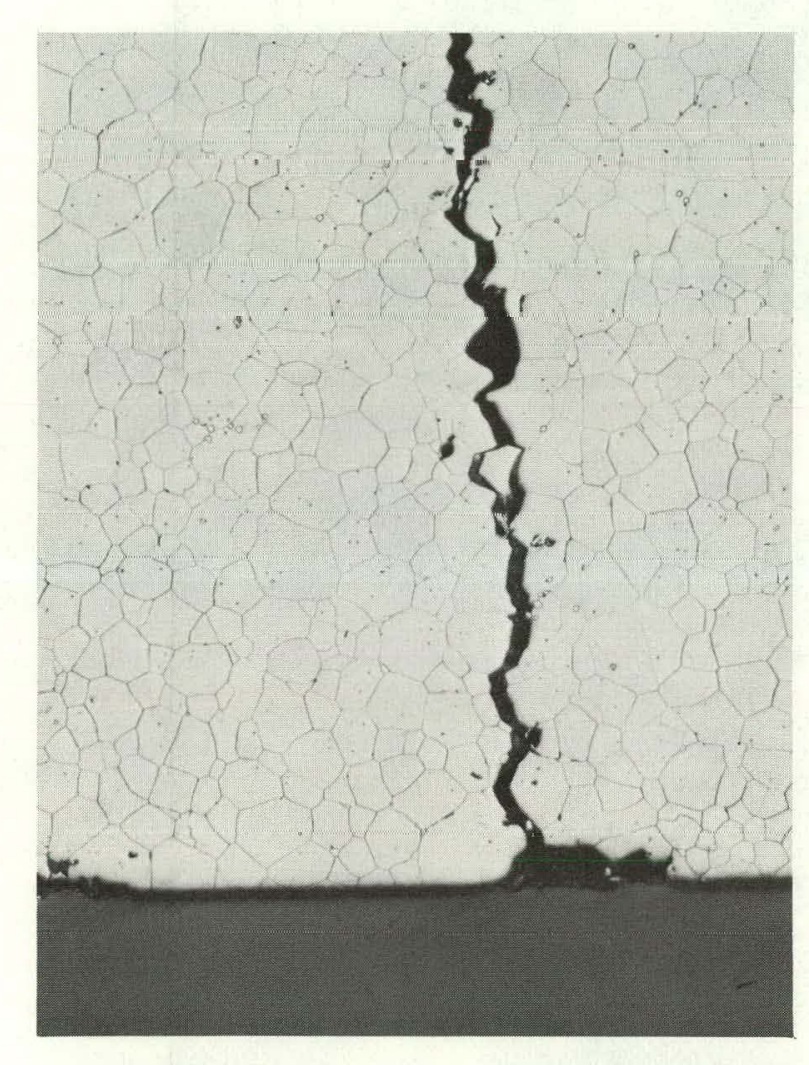

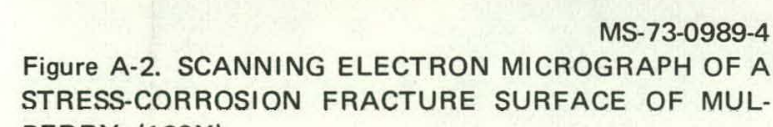
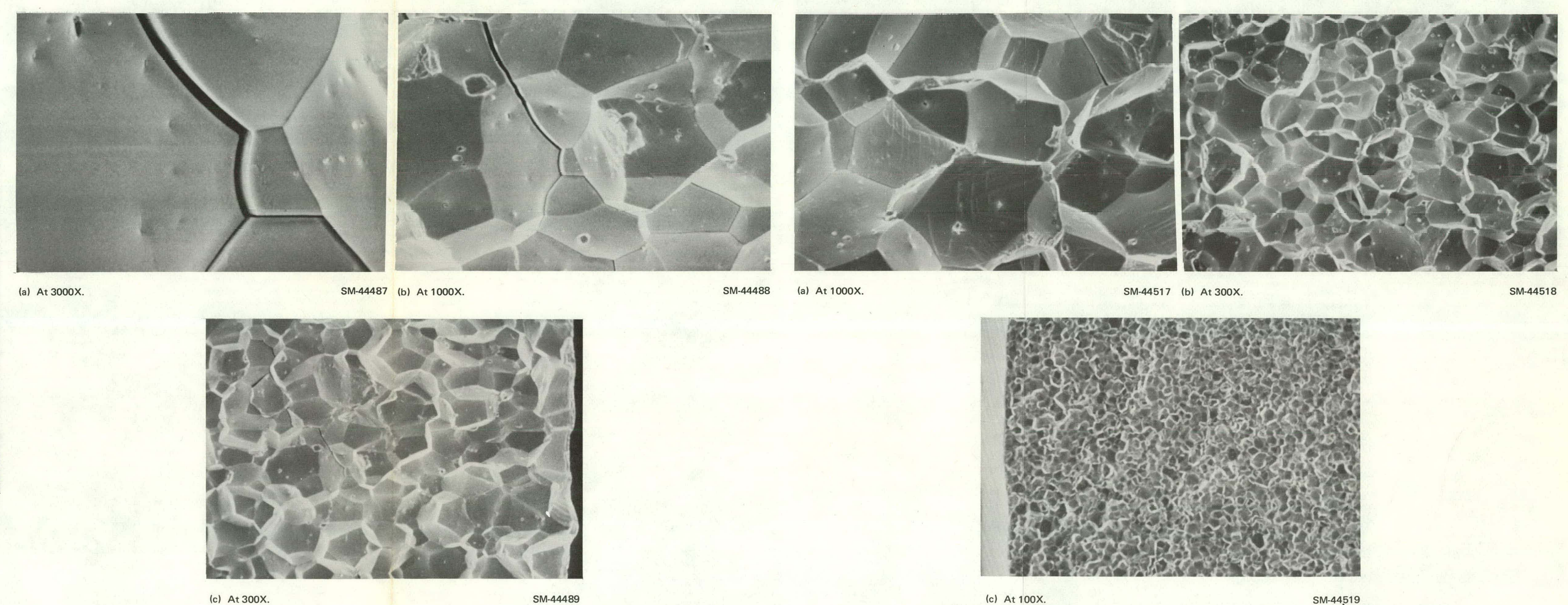

Fivre A3 ScANUMG ELCCTRON MICROG

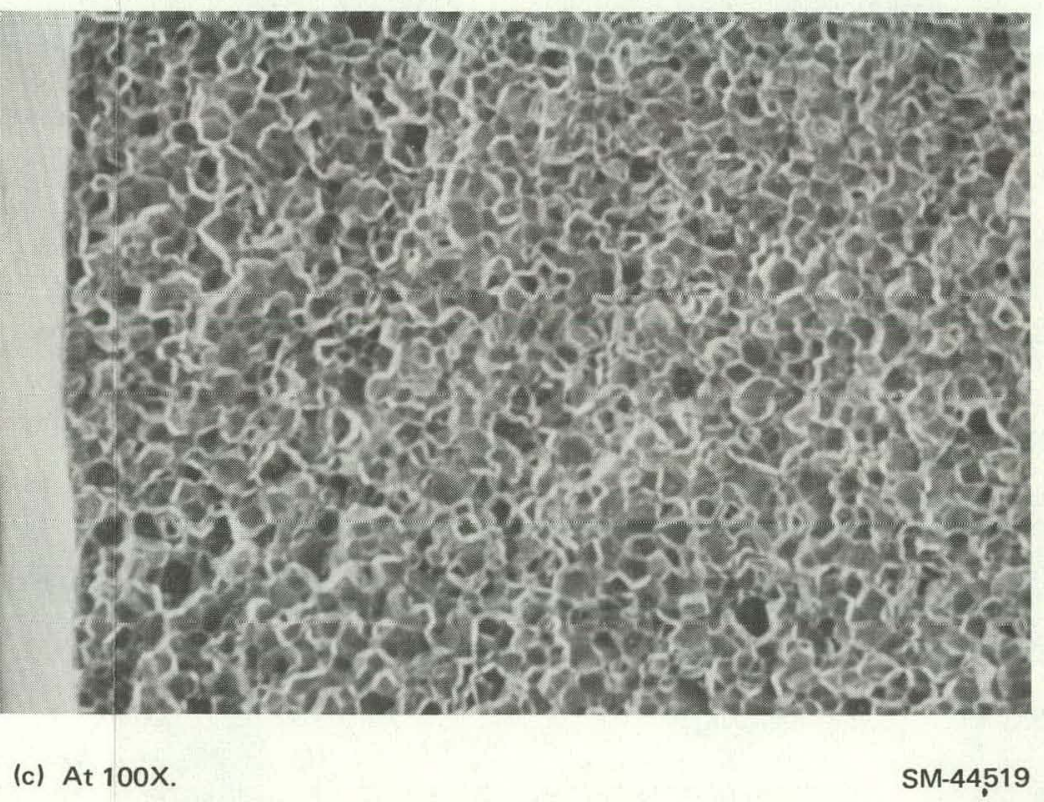



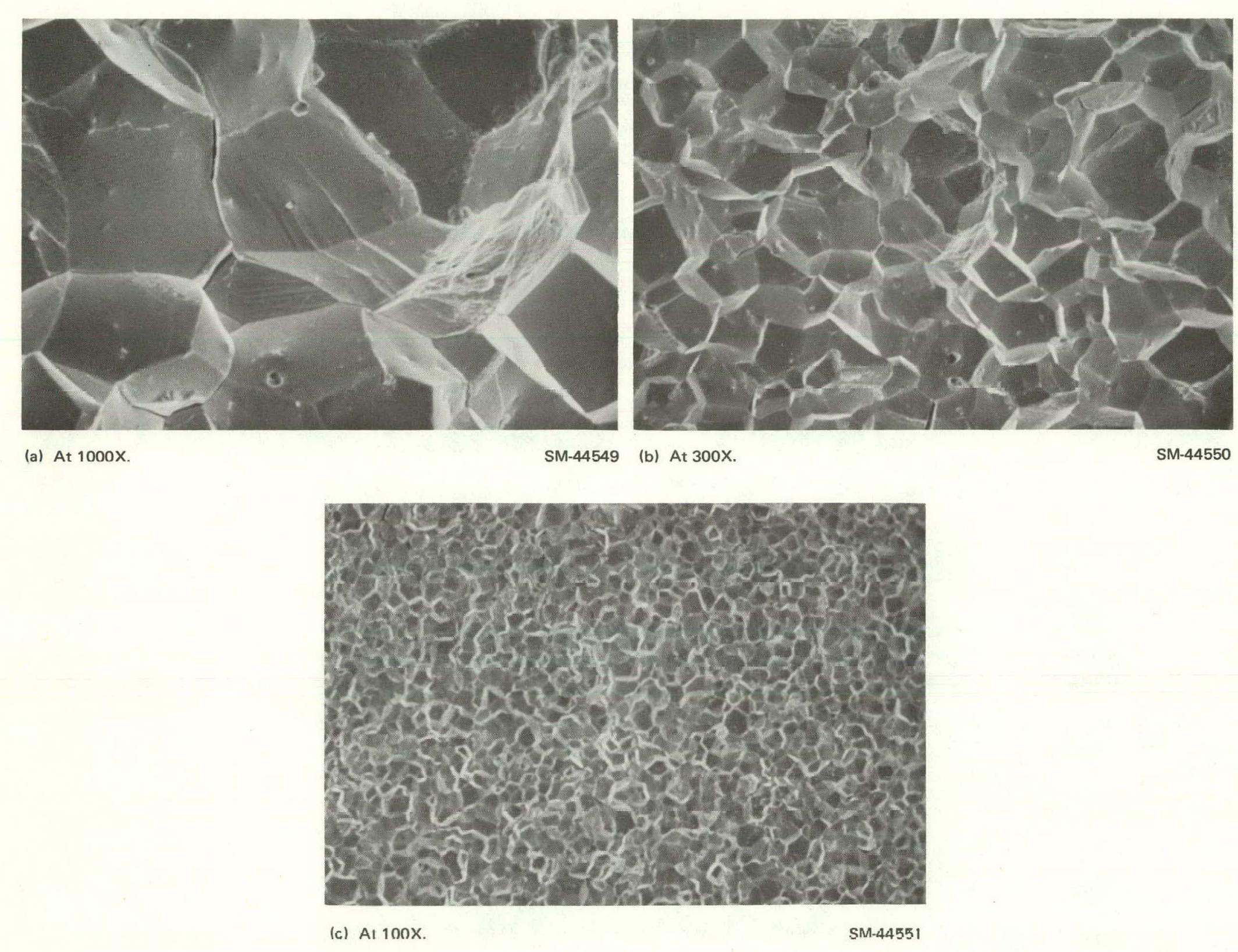

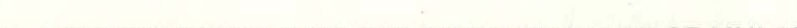
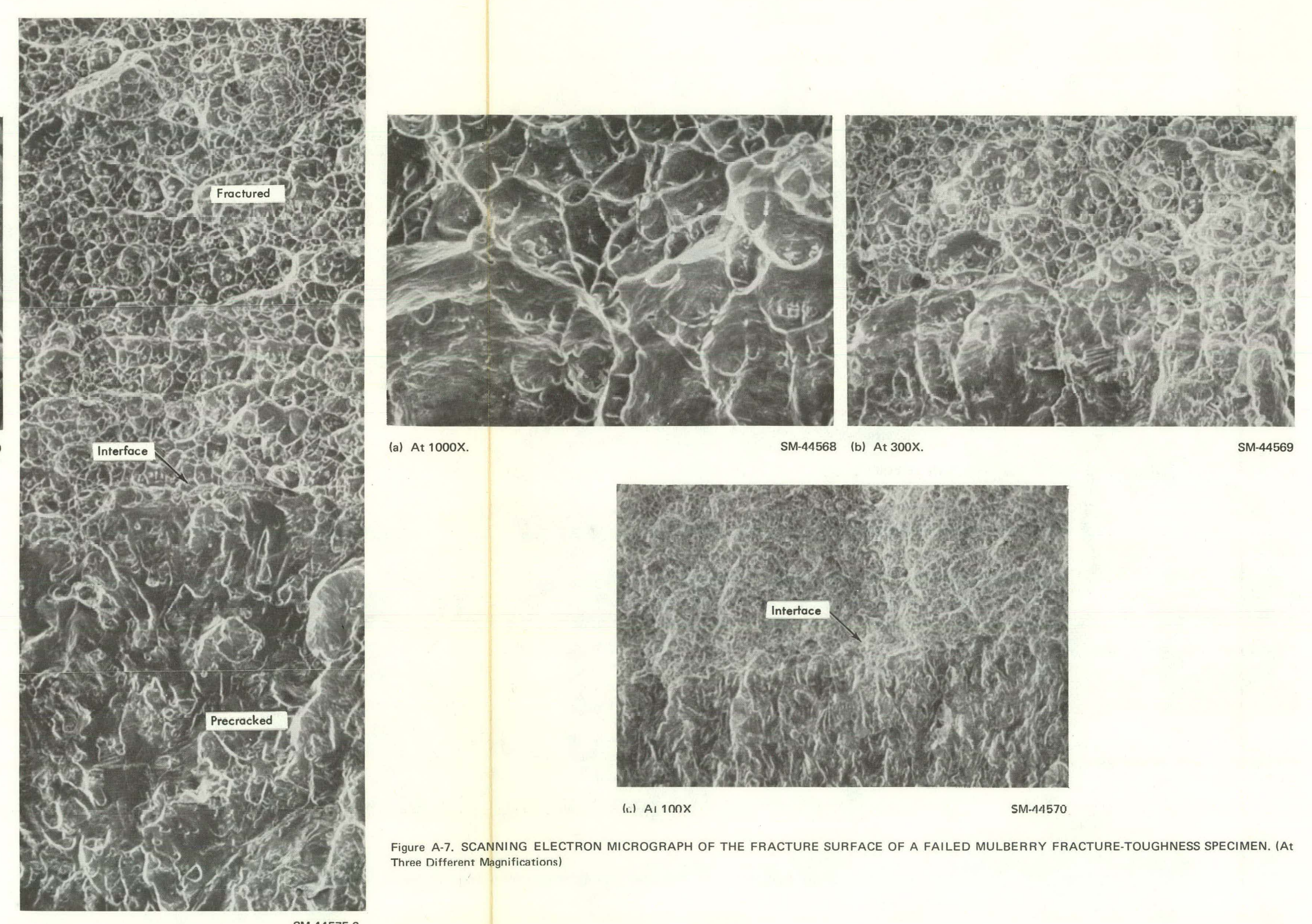

Figure A.7. SCANNING ELEC
Three Different Magnifications)


THE FAACTURE SURFACE OF A FALED MULBERRY
PRERACKED FRACTURE-TOUGHNESS SPECIMEN. 


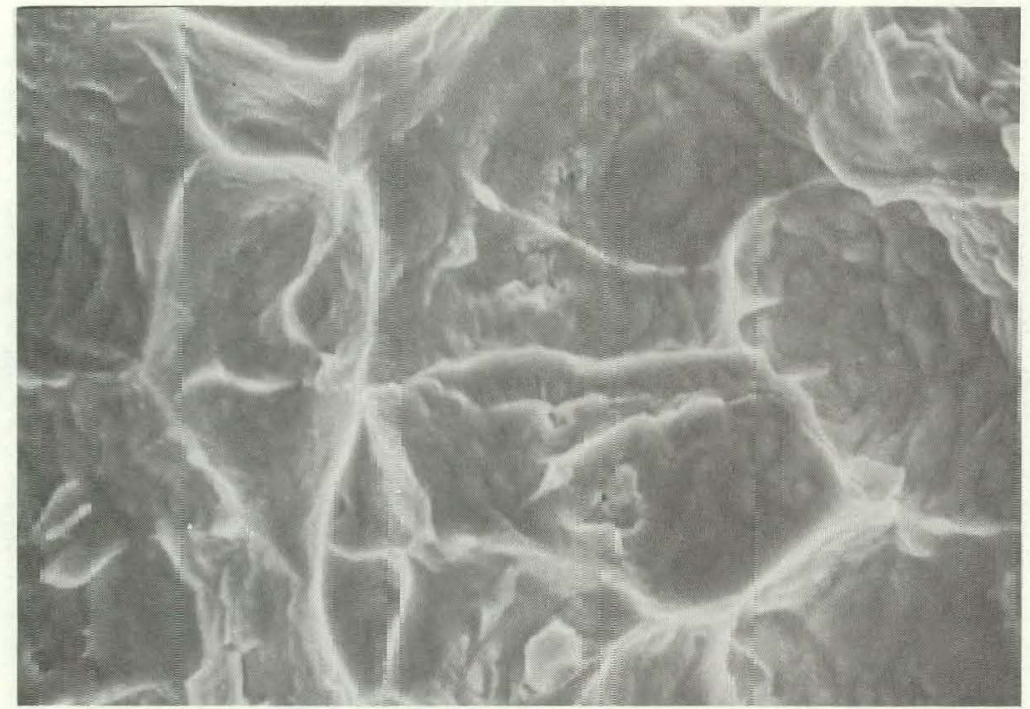

(a) $\Delta$ t $3000 x$

SM-43660

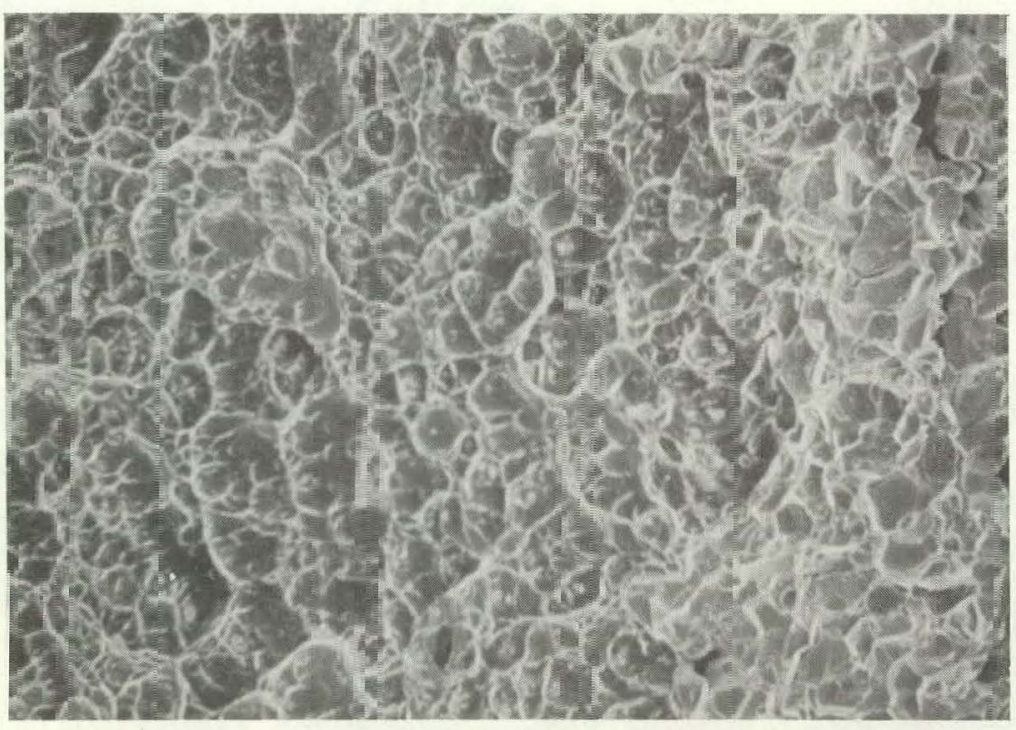

c) At $300 x$.

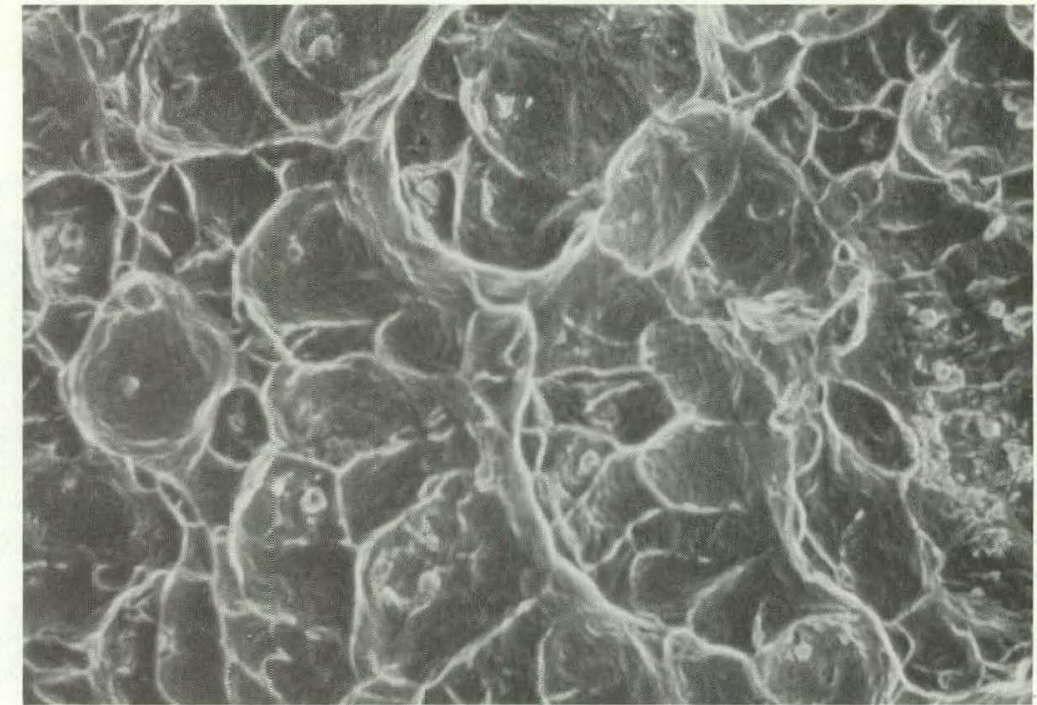

(b) At $1000 x$.

SM-43661

Figure A-8, SCANNING ELECTRON MICROGRAPH OF A TENSILE-OVERLOAD FRACTURE SURFACE OF MULBERRY. 


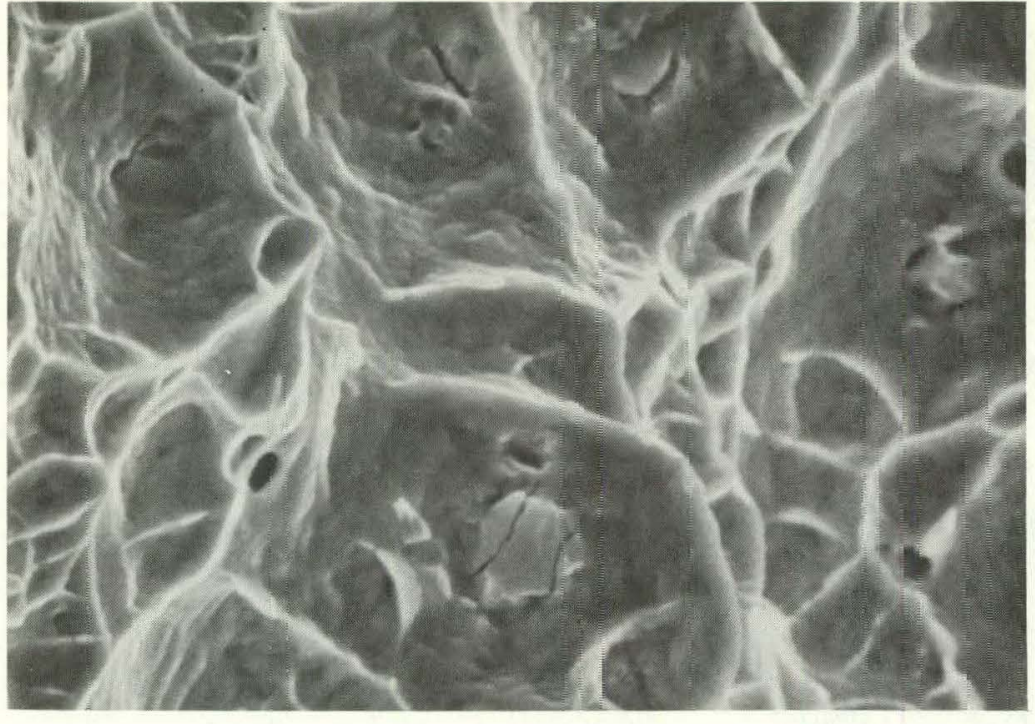

(a) At $3000 x$.

SN1-44552

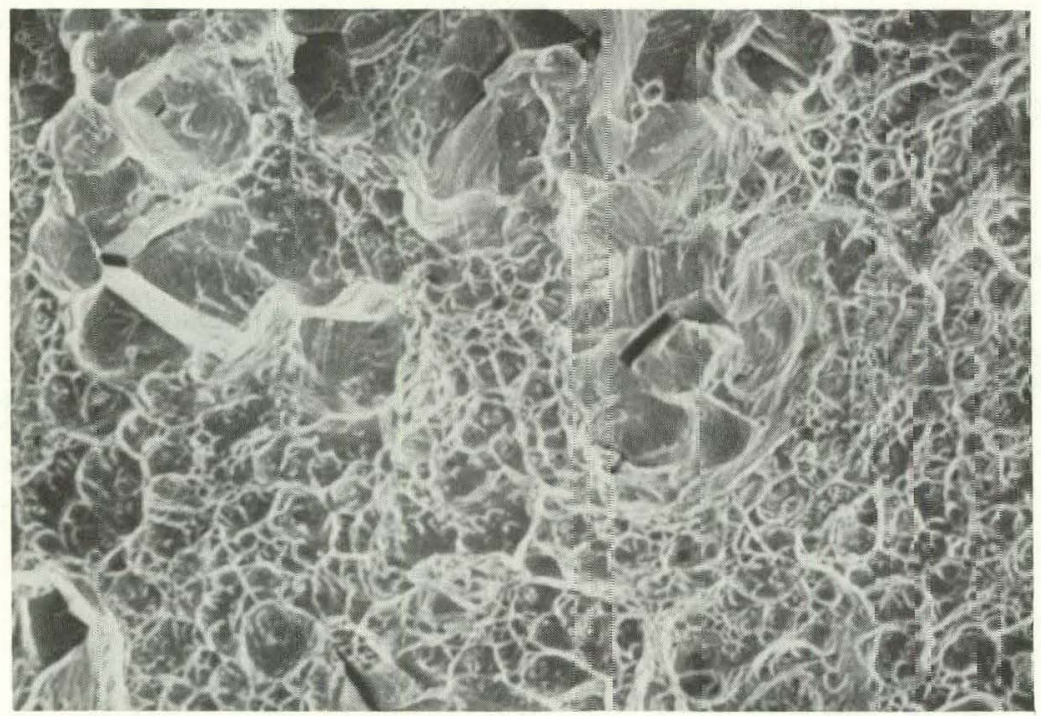

(c) At $300 \mathrm{X}$

SM-44554

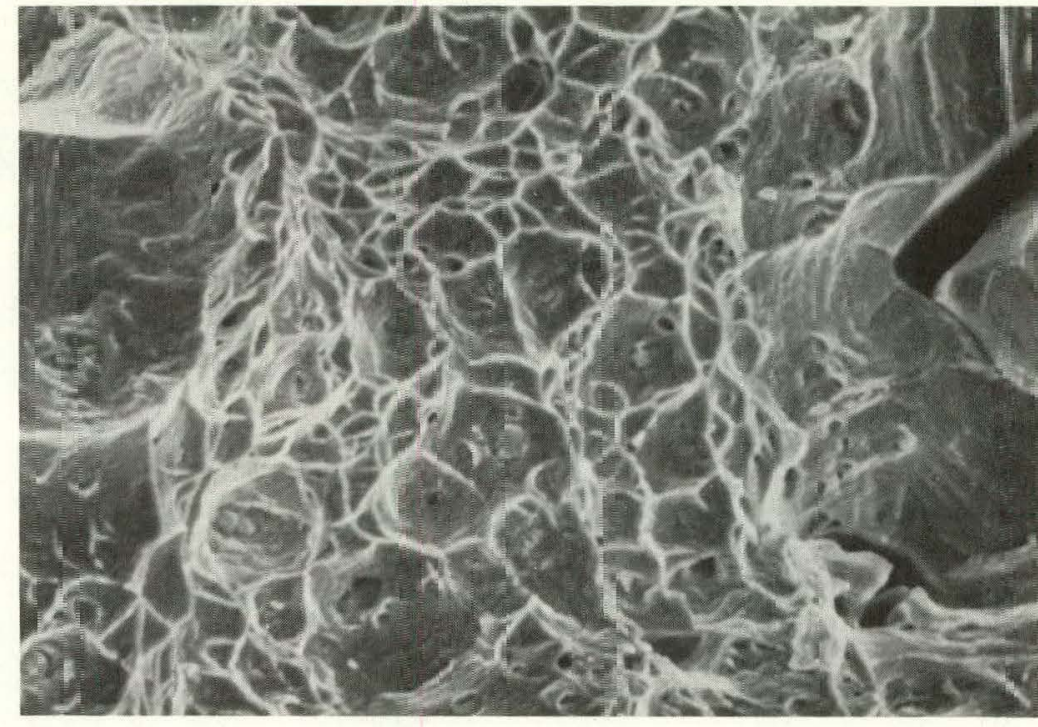

b At $1000 x$.

SM-44553

=igure A-9. SCANNING ELECTRON M CROGRAPH OF A STRESS 工ORROSION FRACTURE $\triangle$ JPFAC $=$ OF FARTIALLY RECRYSTALLIZE MU_BERRY 


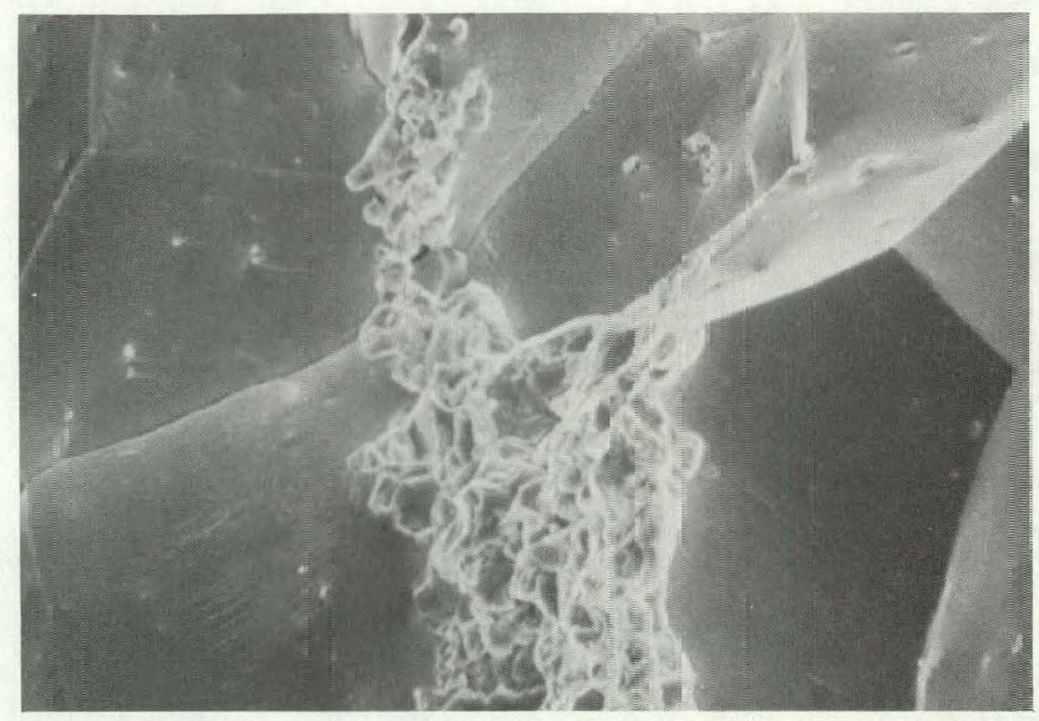

(a) At $1000 x$

SM-43669

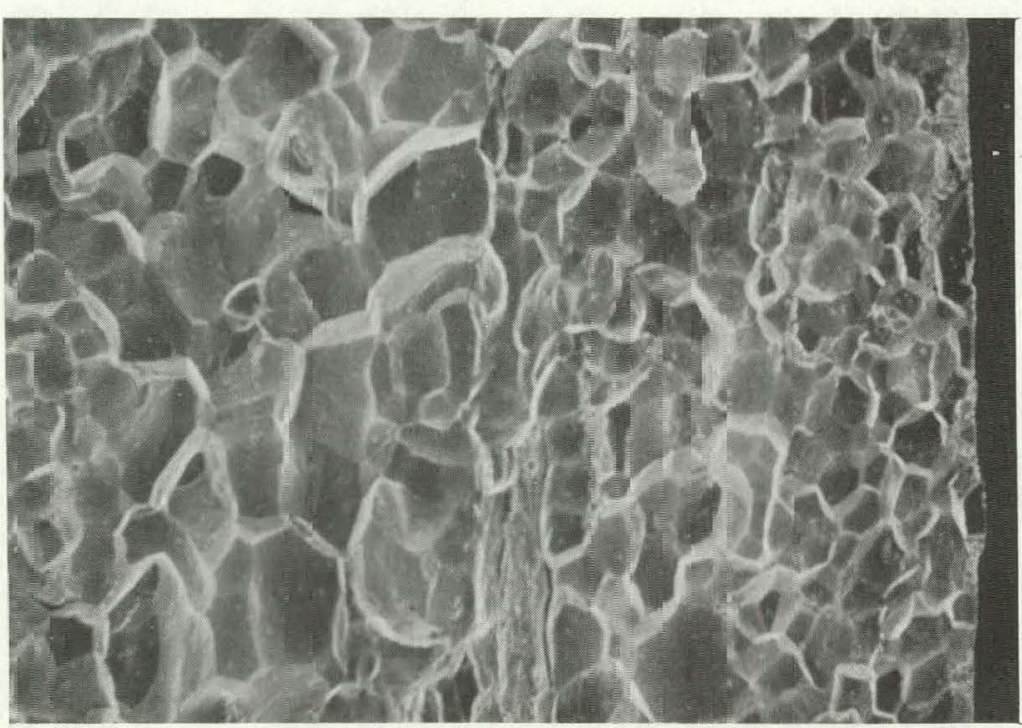

(c) At $100 \mathrm{x}$

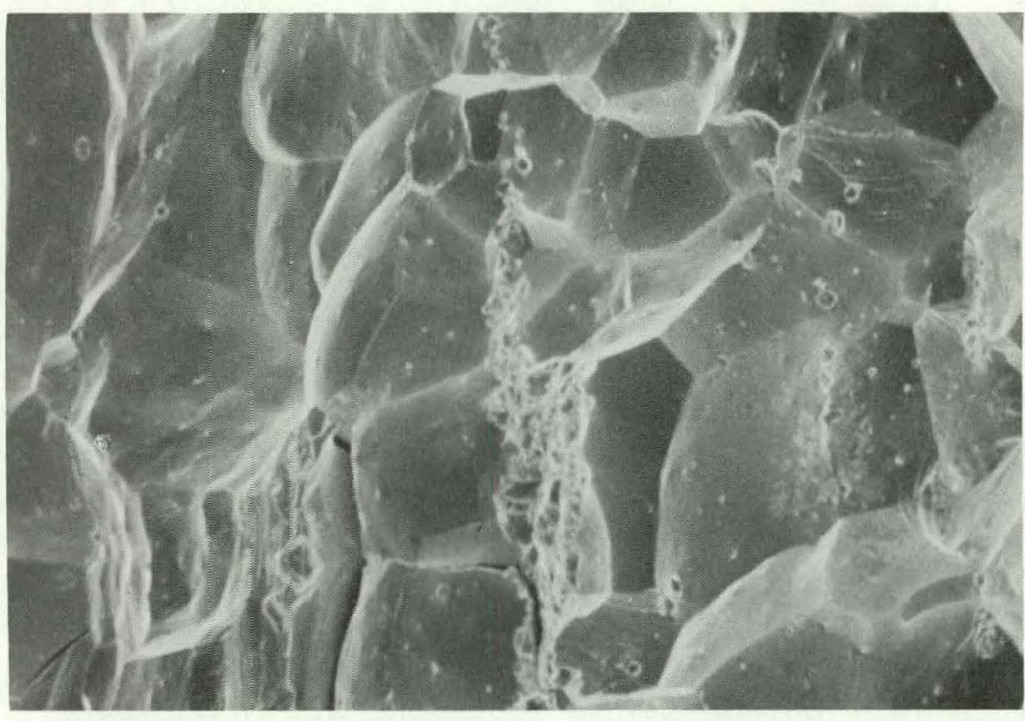

(b) At $300 \mathrm{X}$

SM-43670

Figure A-10. SCANNING ELECTRON MICROGRAPH OF A STRESS CORROSION FRACTURE SURFACE OF MULBERRY WITH 0.25 WEIGHT PERCENT CHROMIUM. 


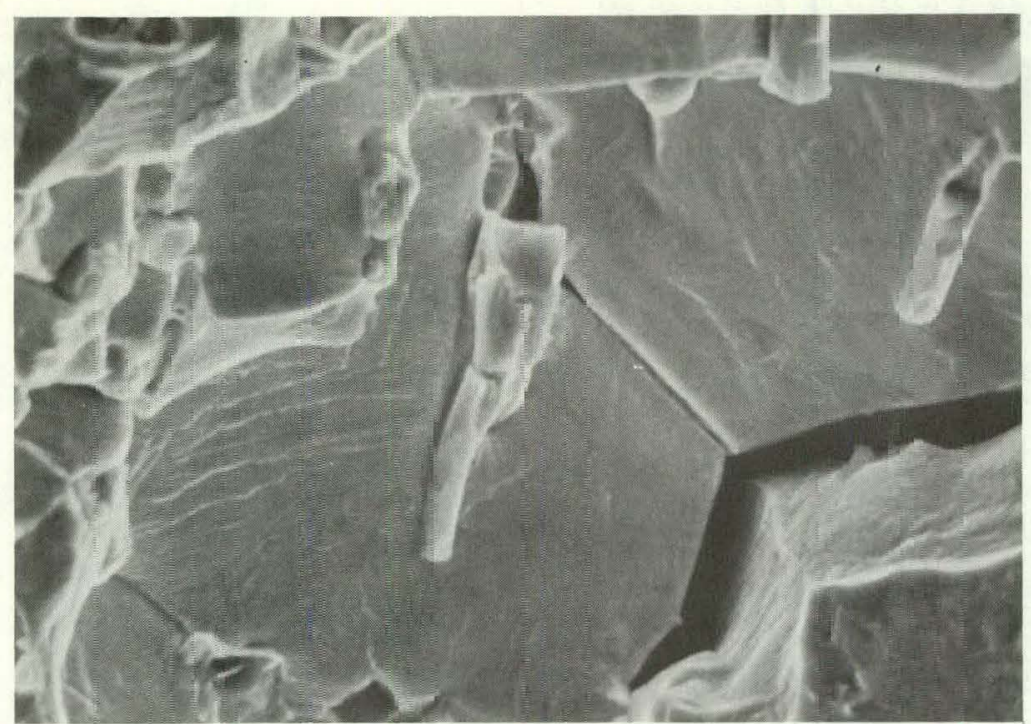

(a) A: $3000 \mathrm{x}$

SM1-43888

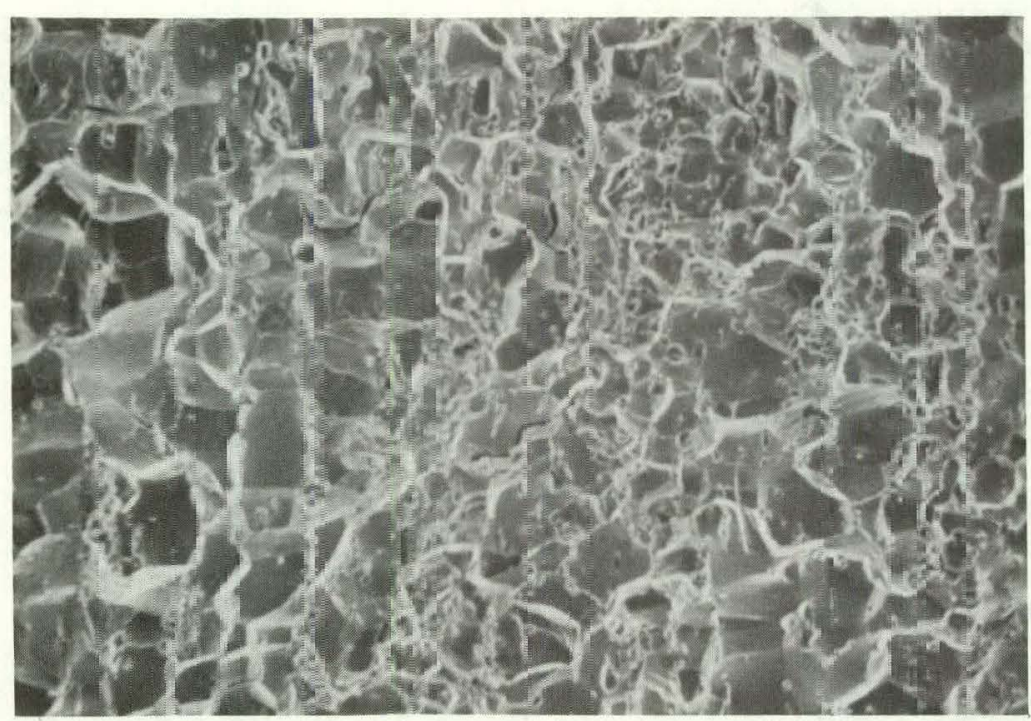

(c) At $300 x$.

SW-43890

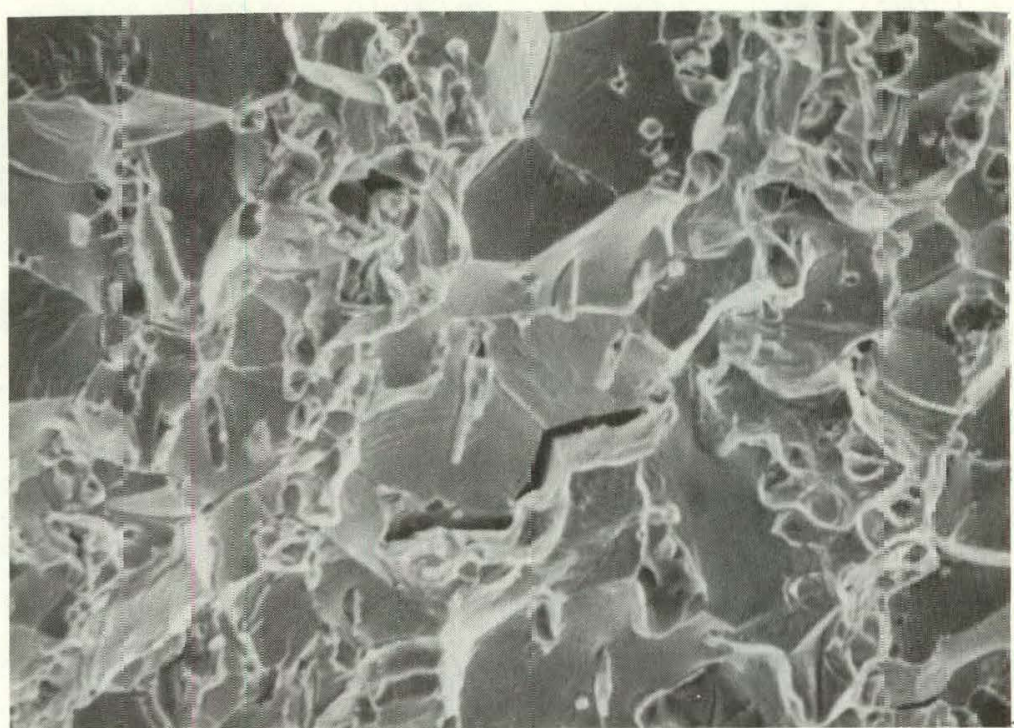

(b) At $1000 \mathrm{X}$

SM- -43889

Figure A-11. SCANNING ELECTRON MICROGRAPH OF A STRESS CORROSION FRACTURE SURFACE OF MULBERRY WITH 0.75 WEIGHT PERCENT GERMANIUM. 


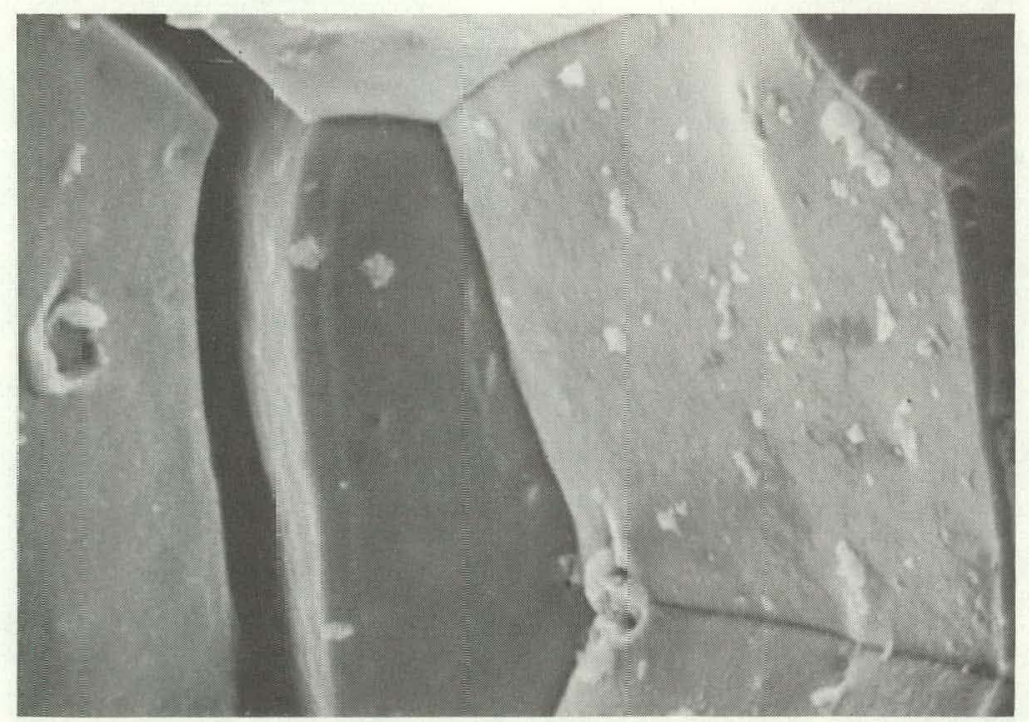

(a) At 3000X.

SM-43703

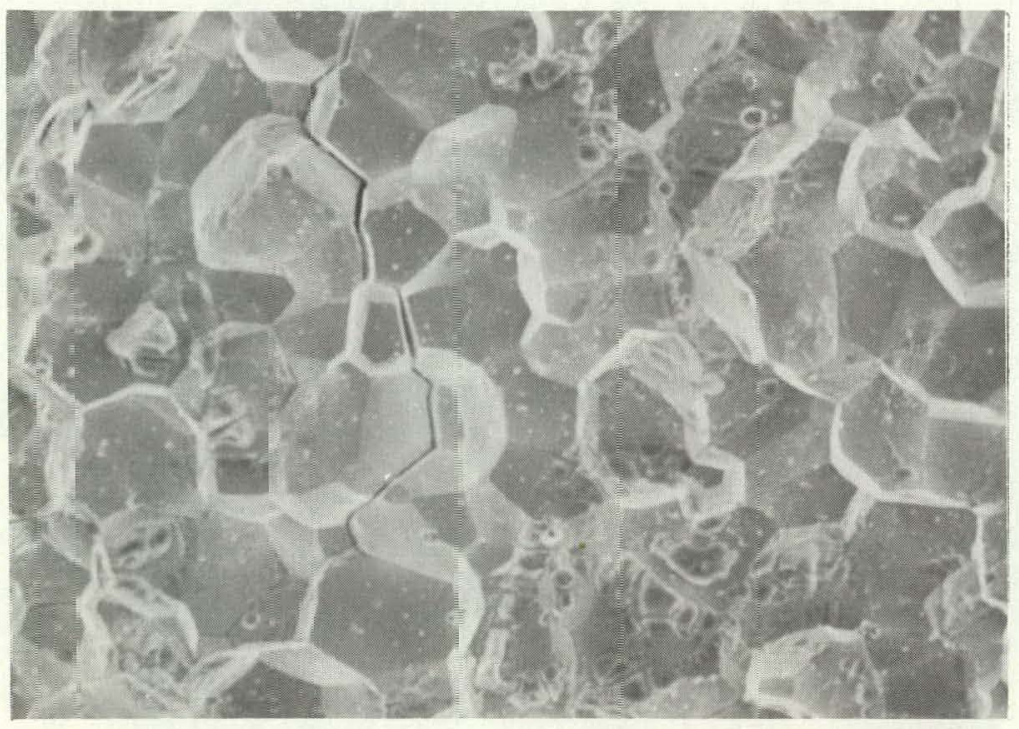

(c) f.t $300 x$.

SM-43705

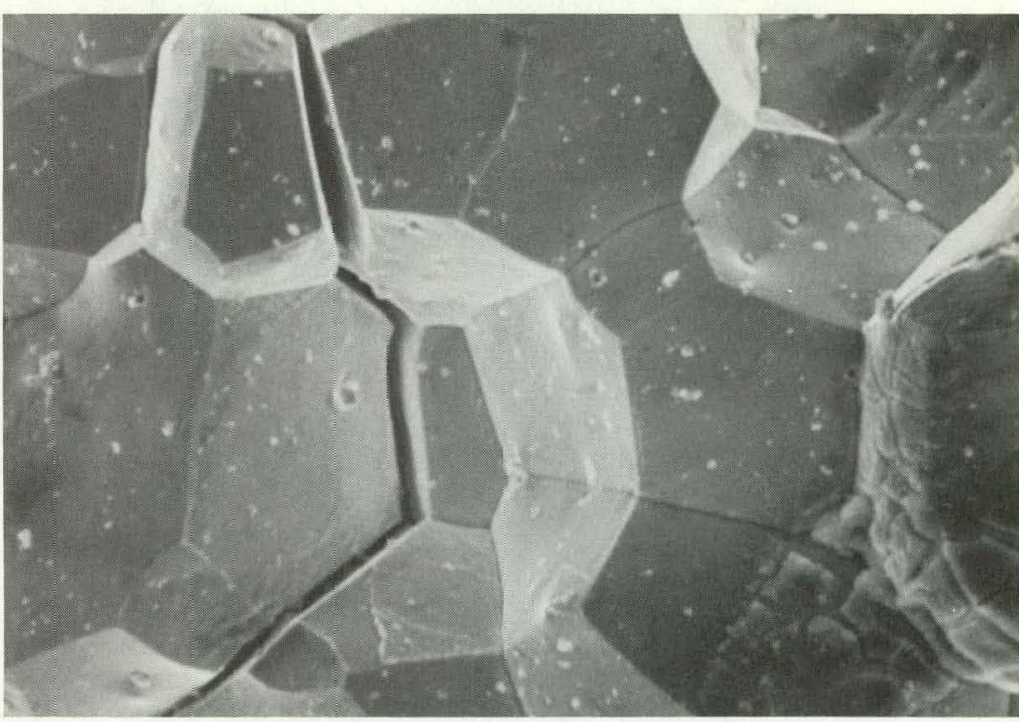

(b) At $1000 x$.

SM-43704

Figure A-12 SCANNING ELECTRON MICROGRAPH OF A STRESSCORROSION FRACTURE SURFACE OF URANIUM-6.5 WEIGHT PERCENT NIOBIUM-1.5 WEIGHT PERCENT ZIRCONIUM. 


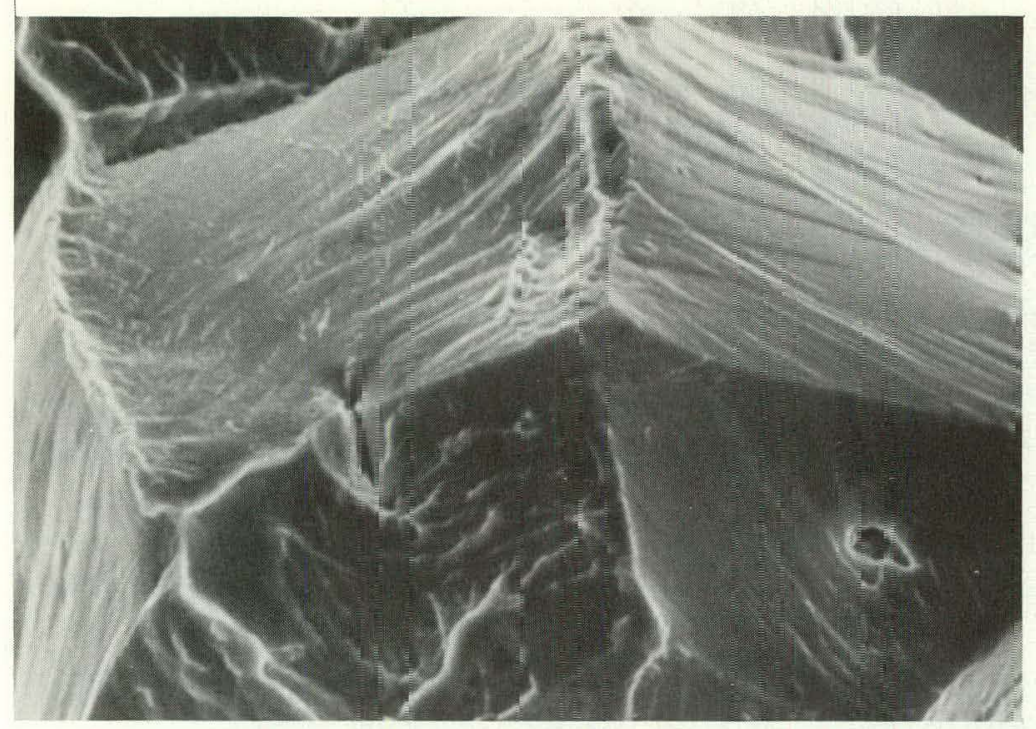

(a) At $3000 x$.

SM-43689

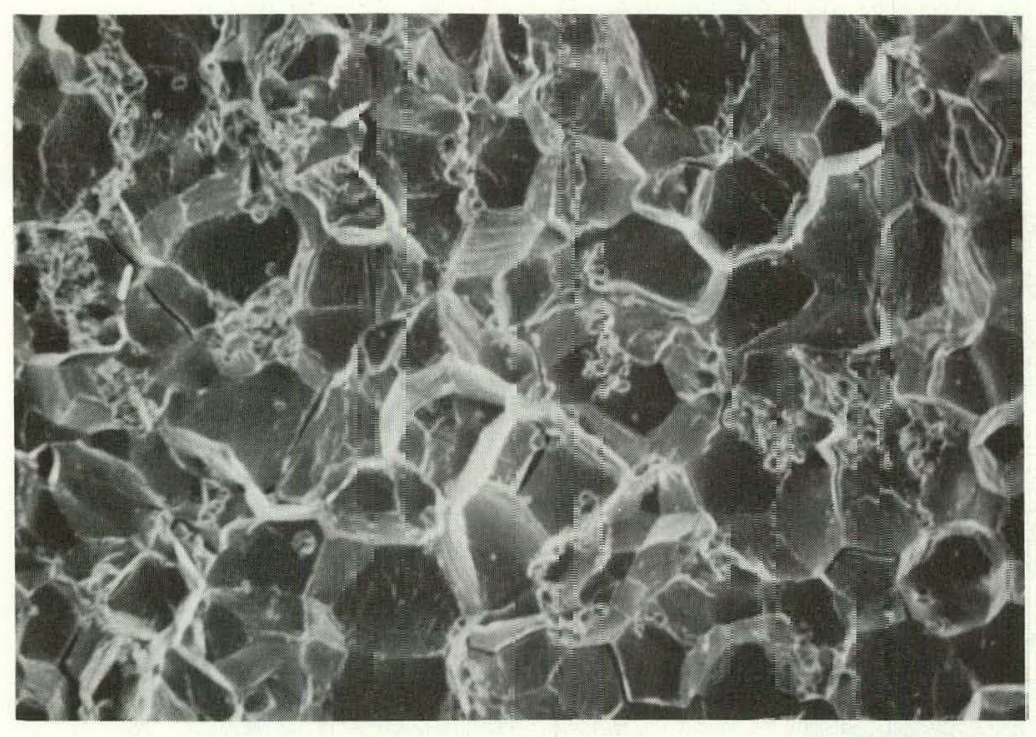

(c) At $300 x$.

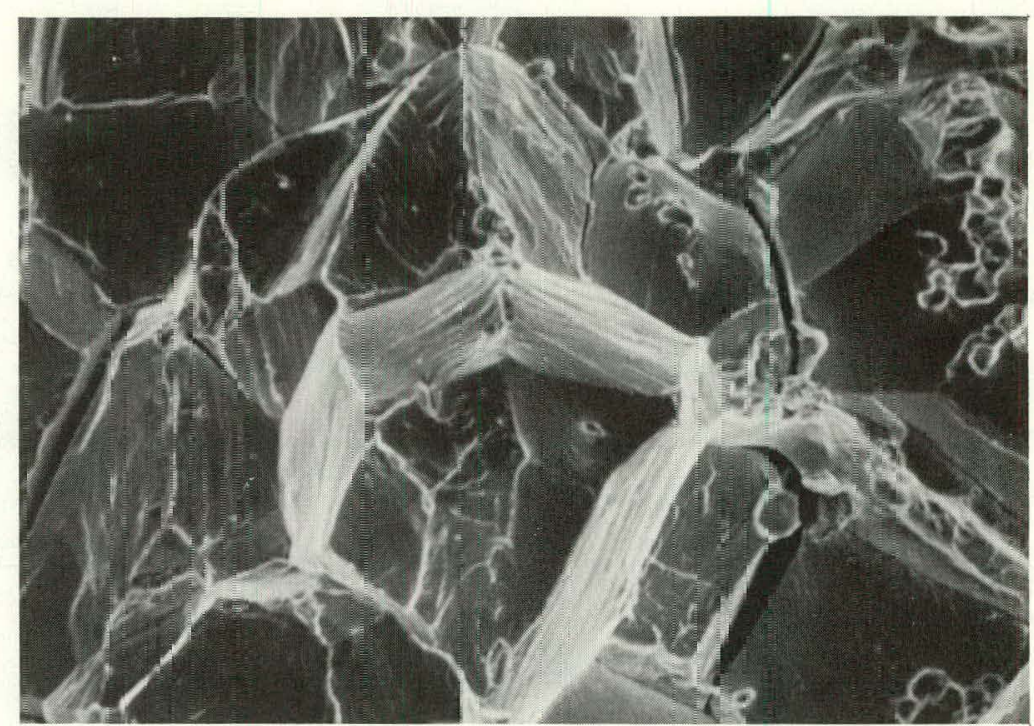

(b) At 1000x.

SM-43690

Figure A-13. SCANNING ELECTRON MICROGR.AF' OF A STRESSCORFOSION F=ACTURE SURFACE OF URANIUM.7.5 WEIGHT PERCENT NIOBIUM-2.5 WVEIGHT PERCENT HAFNIUM. 

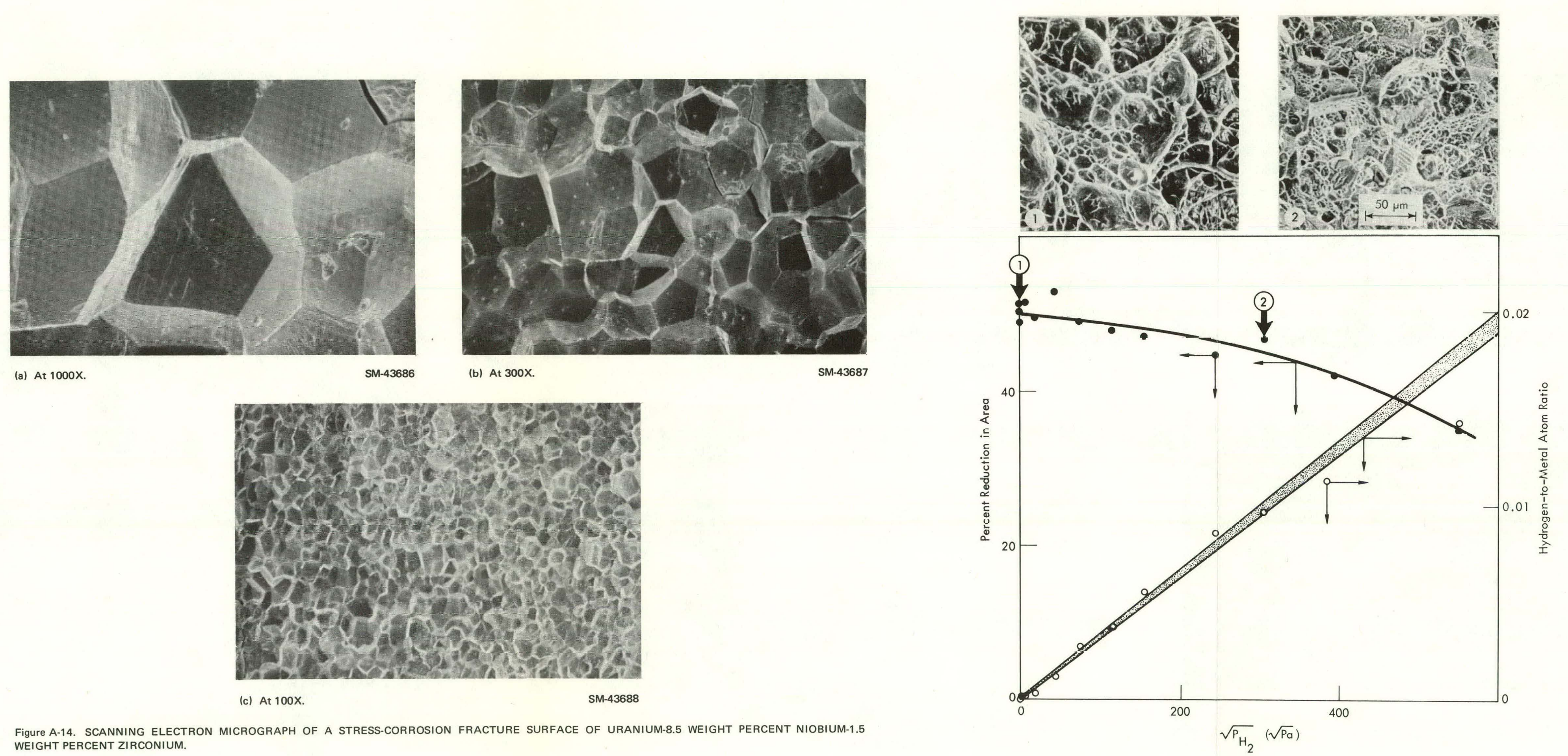

Figure A.19. SCANNING ELECTRO
WEIGHT PERCENT ZIICONIUM.

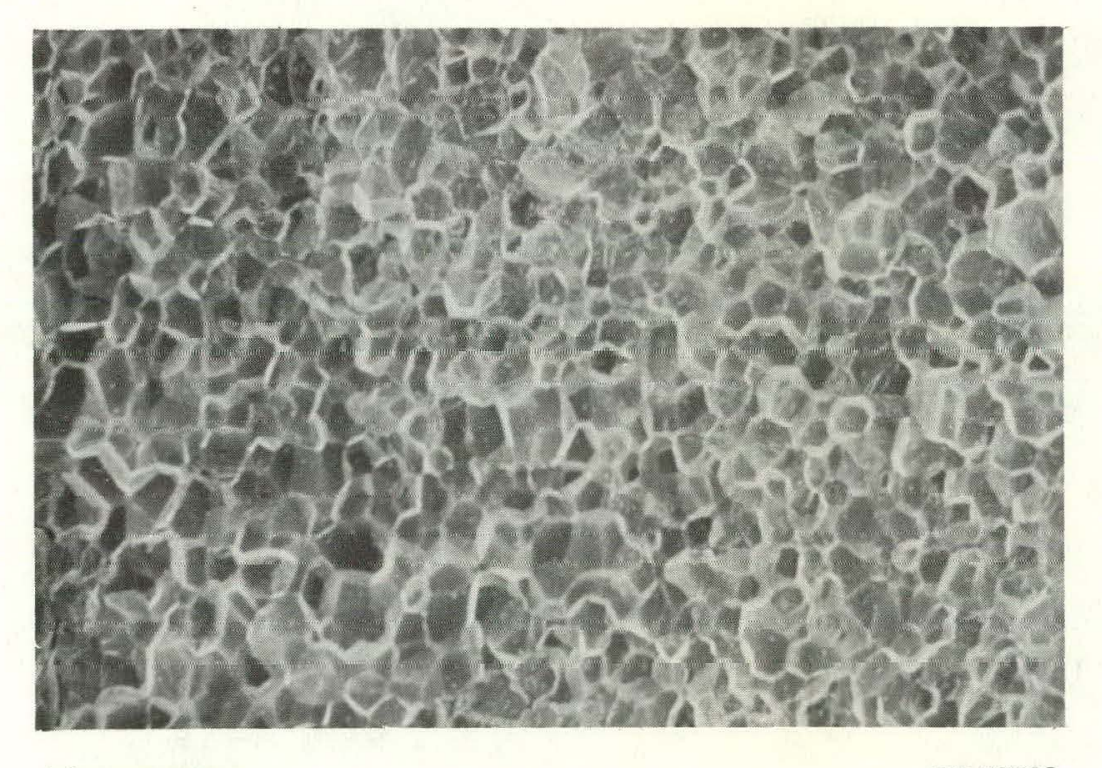



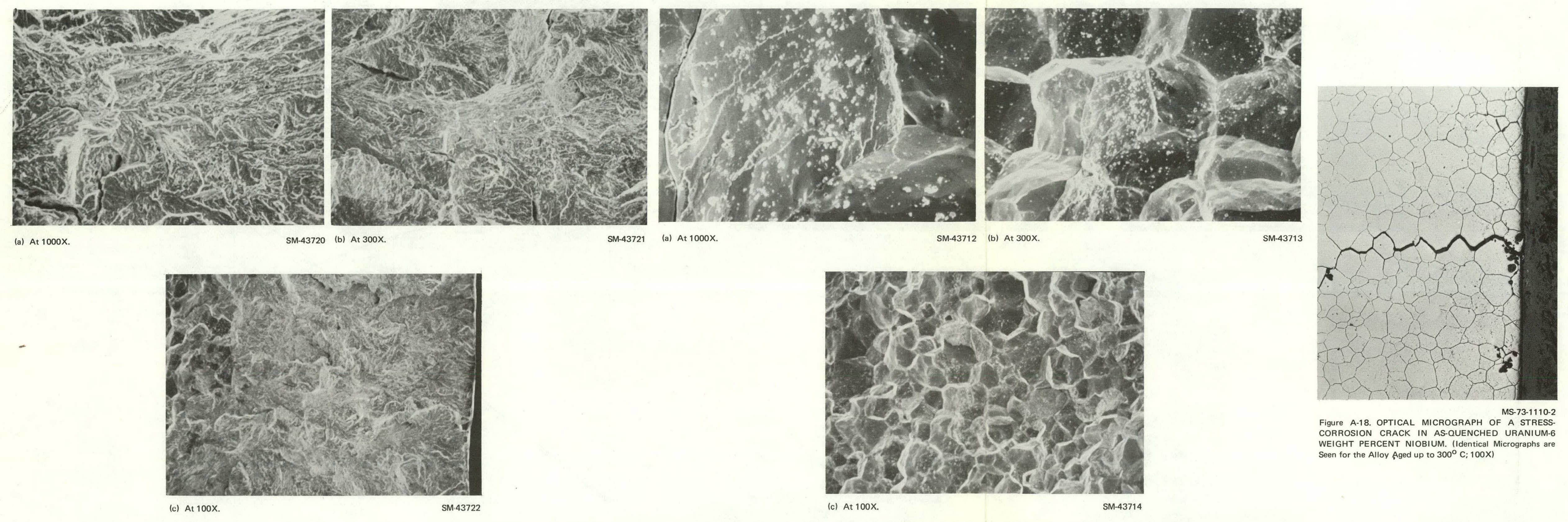

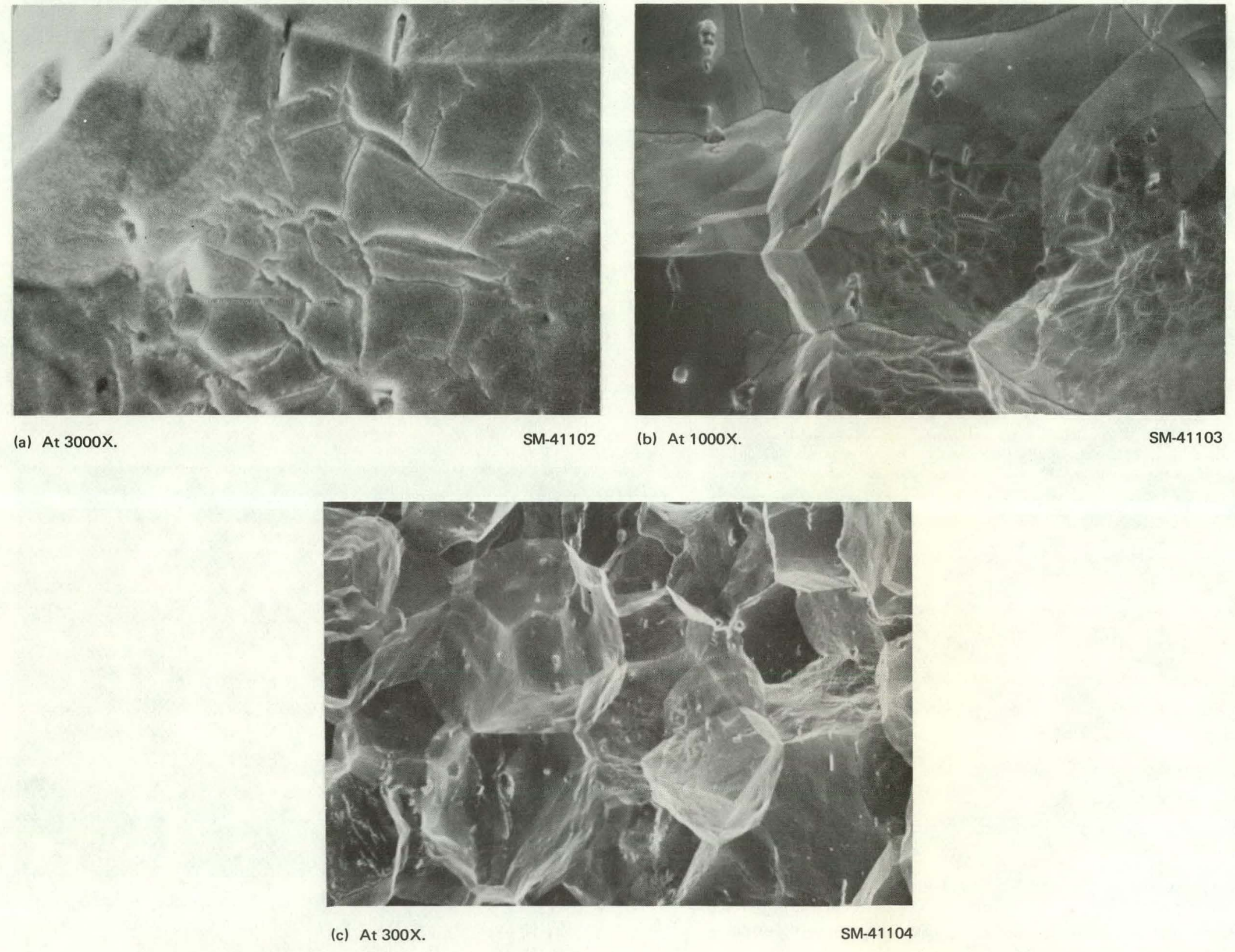

Figure A-19.
NIOBIUM.
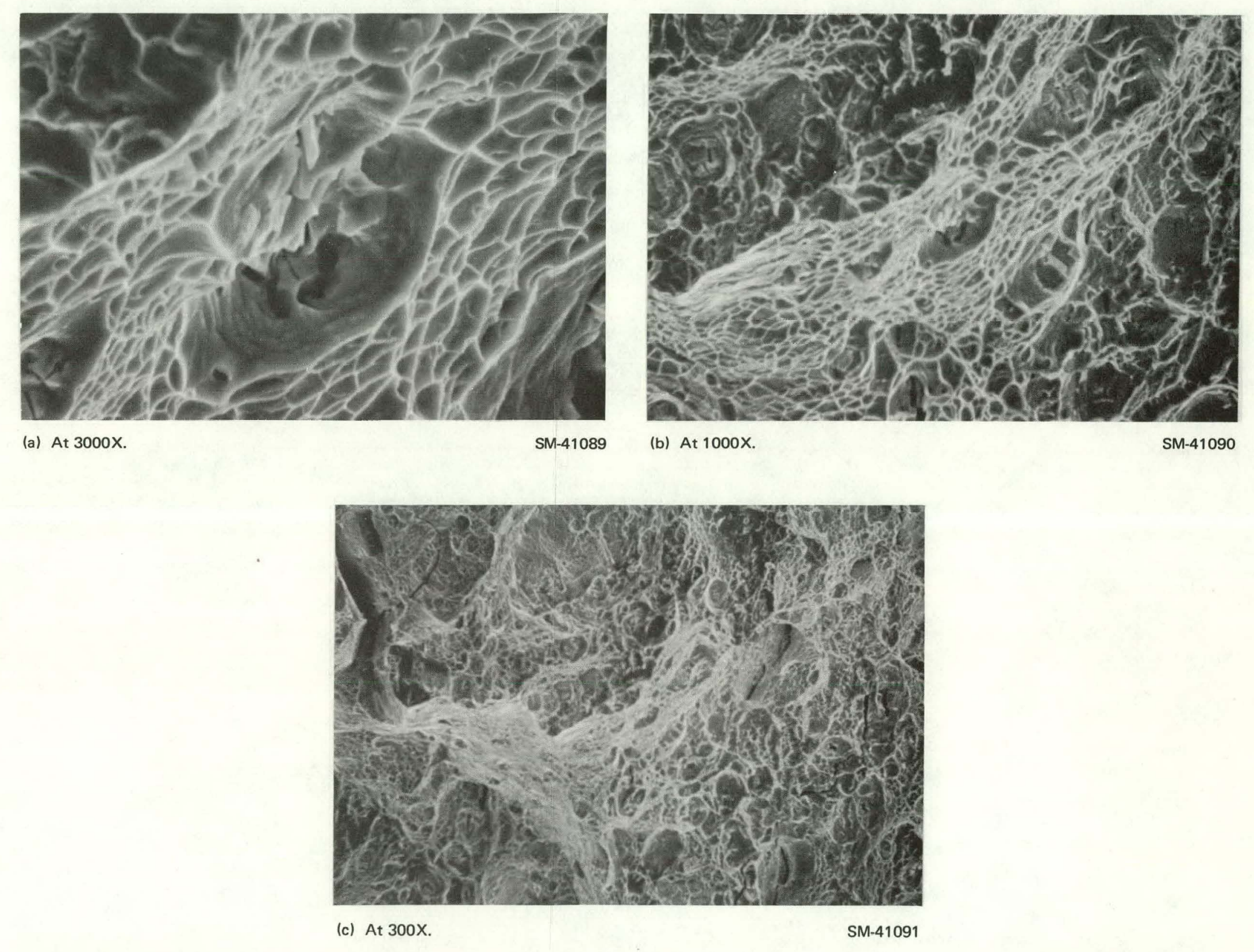

Flgure A-20. SCAN
AGED AT $300^{\circ}$ C. 

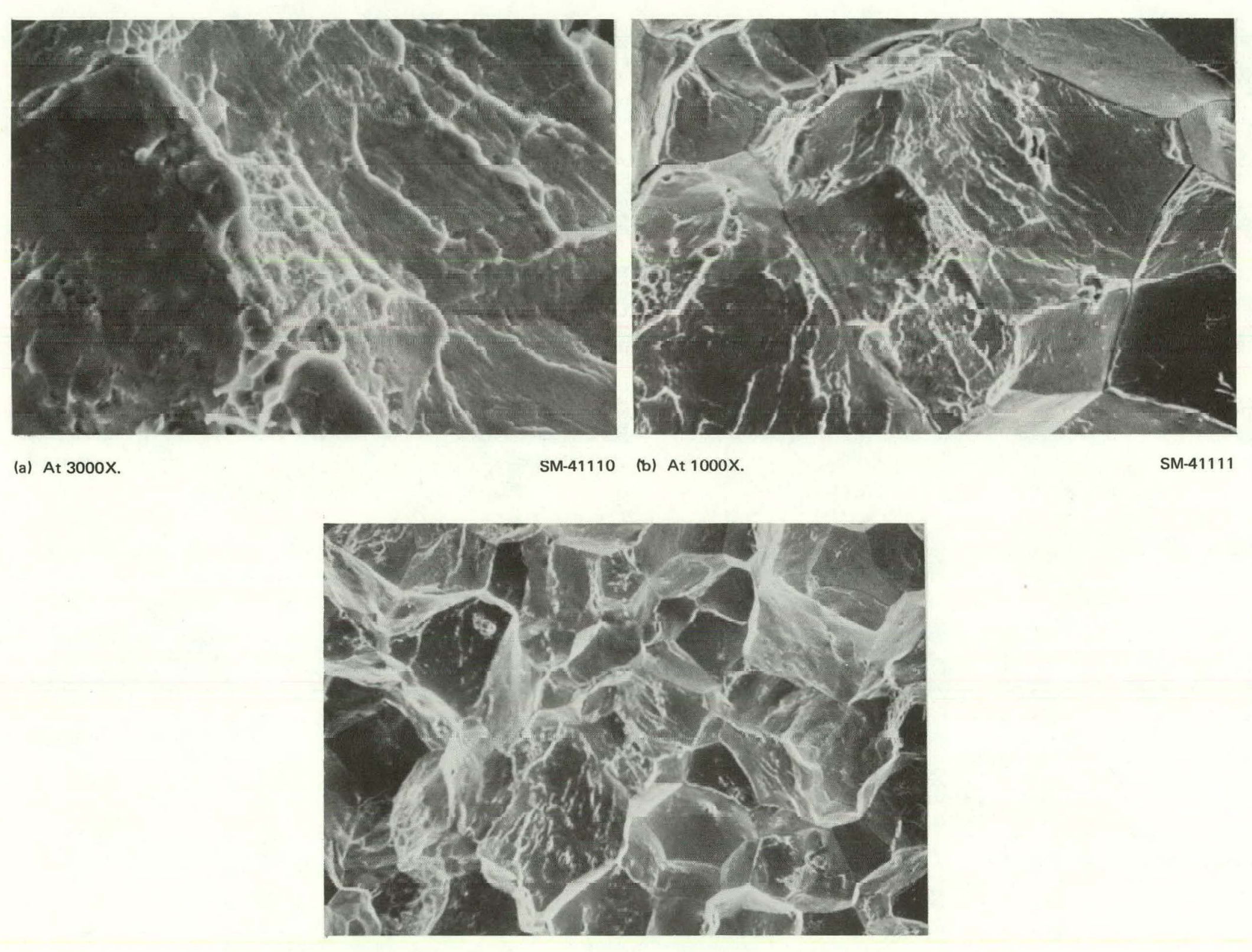

Figure A-21. SCA
AGED AT $300^{\circ} \mathrm{C}$.

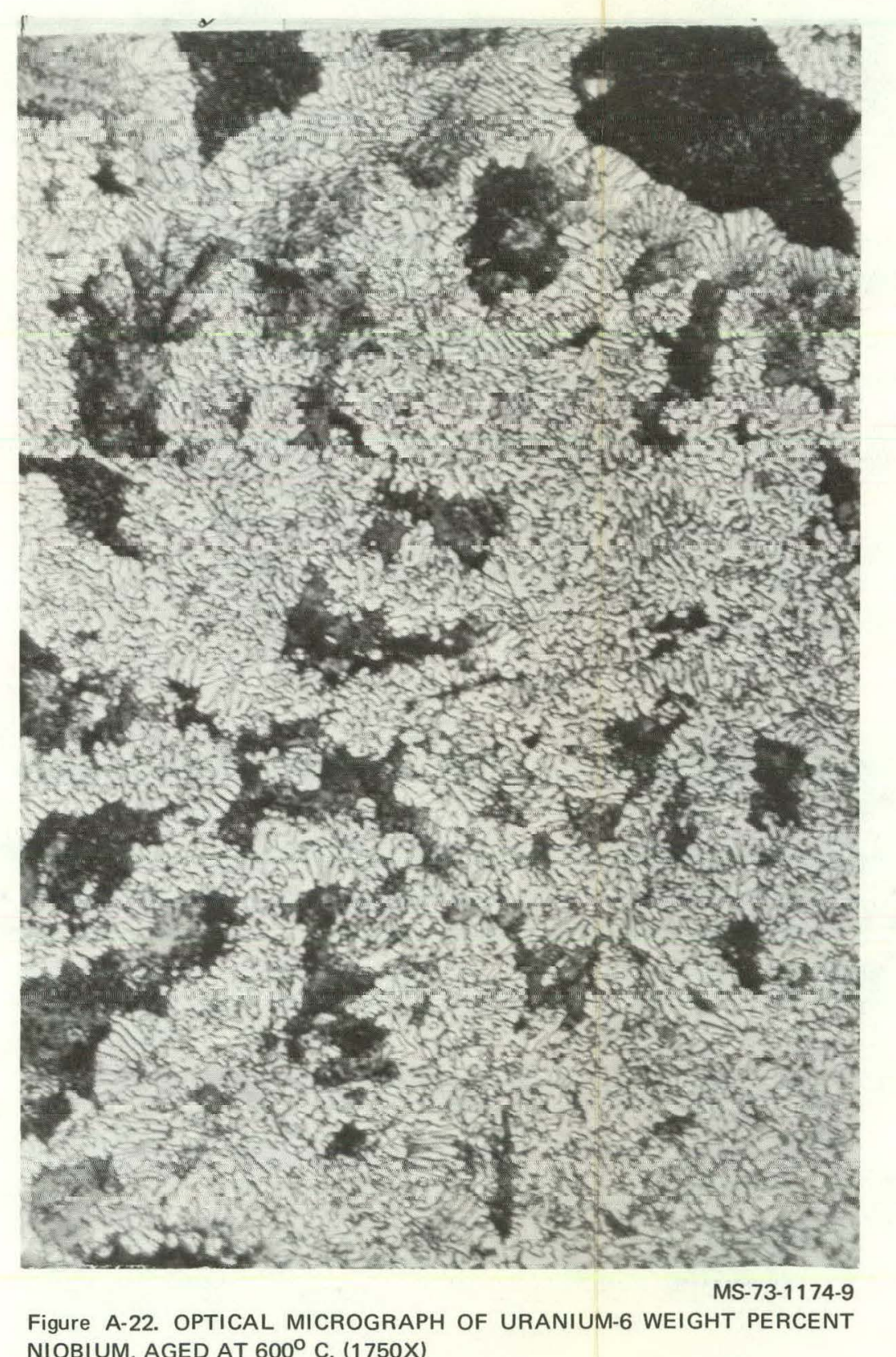

Figure A-22. OPTICAL MICROGRAPA

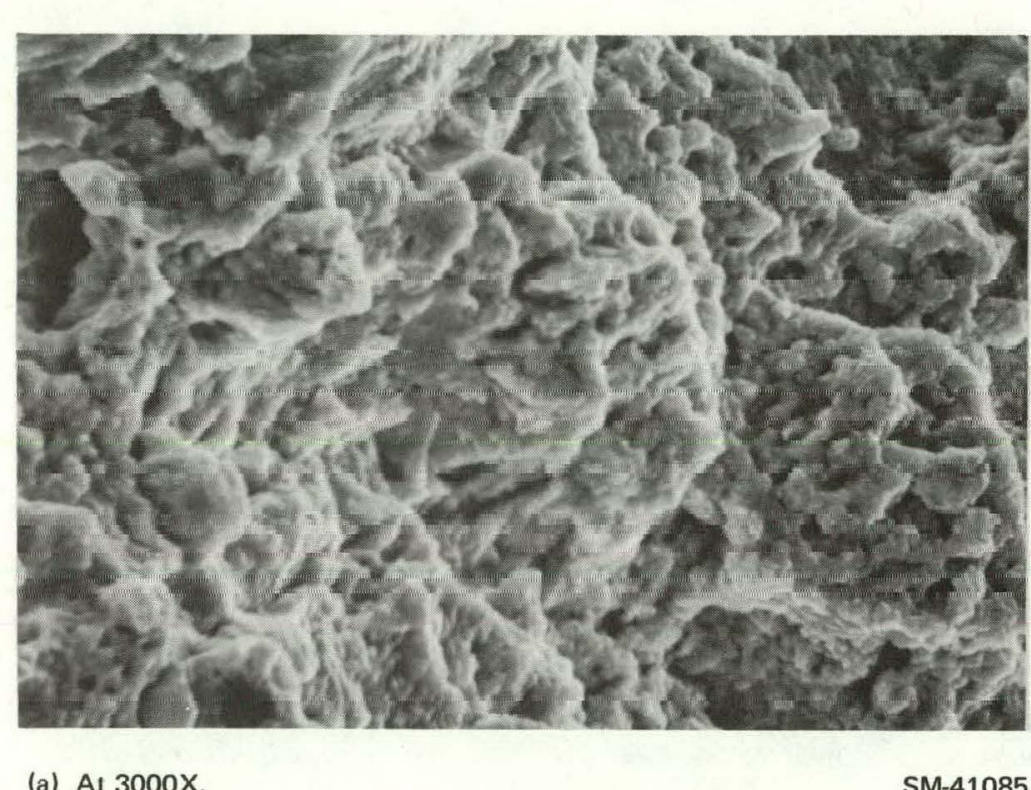

(a) A $3000 x$

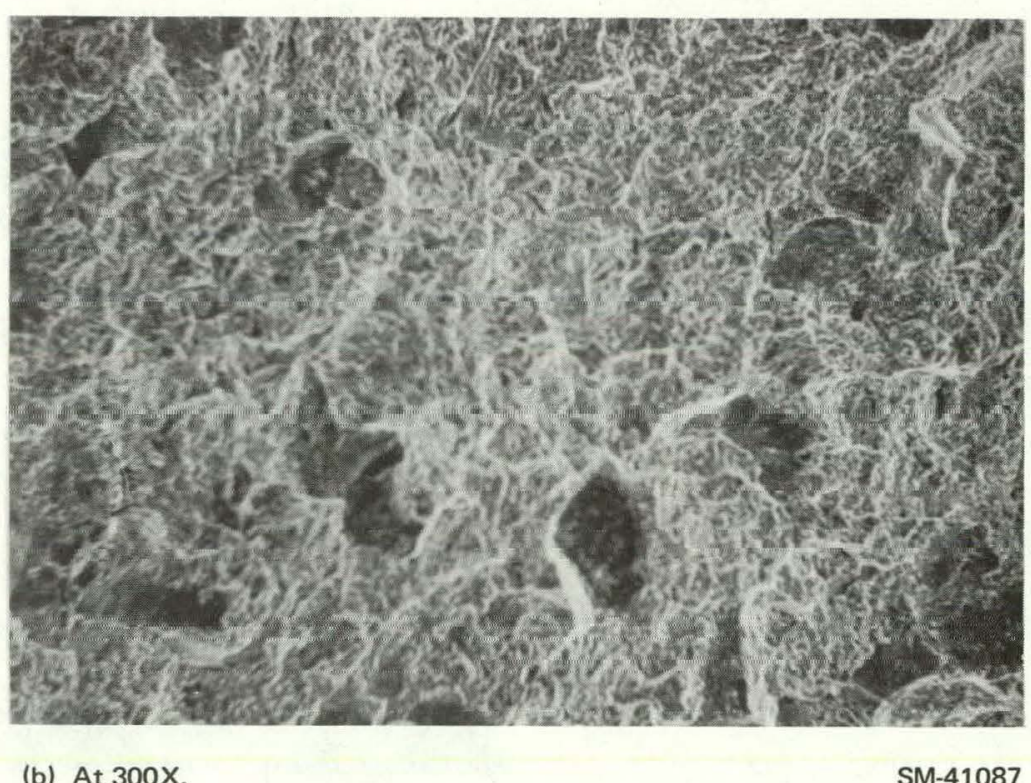

(G) At $300 x$

Figure A.23. SCANNING ELECTRON MICROGRAPH OF A STRESS
CORRBSION FRACTREE SURFACE OF URANIUM-6 WEIGHT PERCENT
NIOBIUM, AGED AT 600 

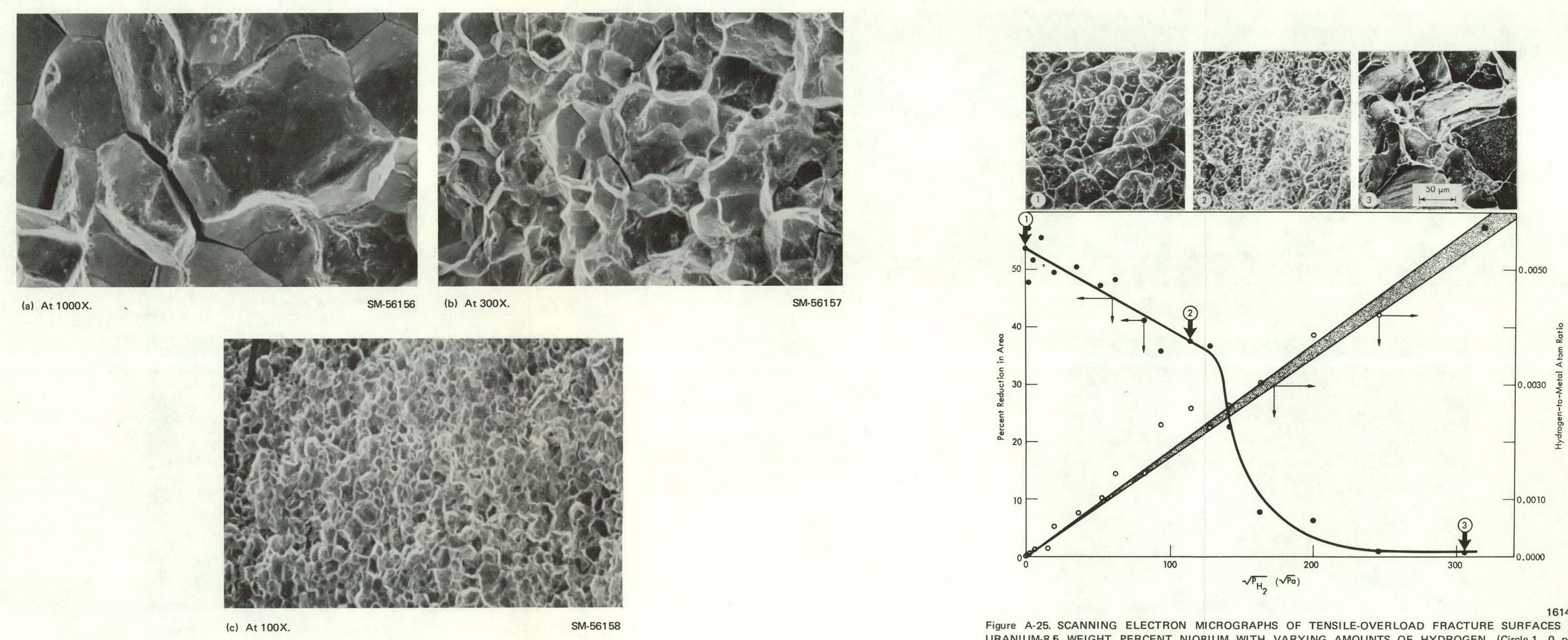

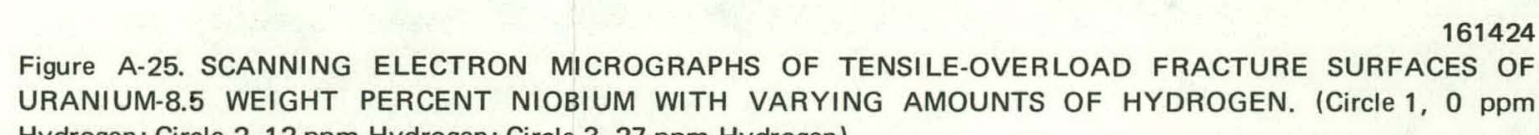



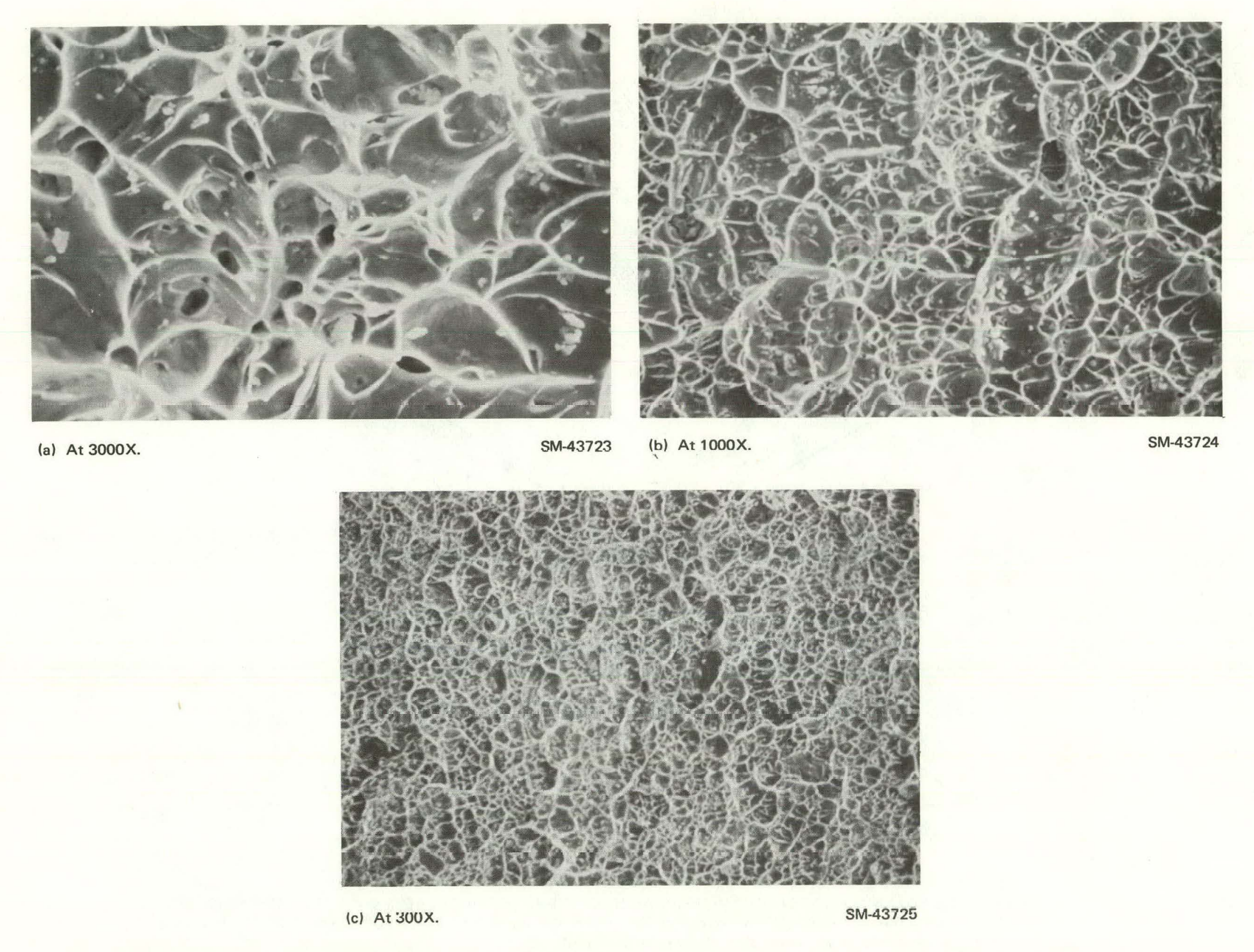

Figure A-26. SCANNING ELECTRON MICROGRAPH OF TENSILE-OVERLOAD FRACTURE SURFACE OF URANIUM-10 WEIGHT PERCENT NIOBIUM
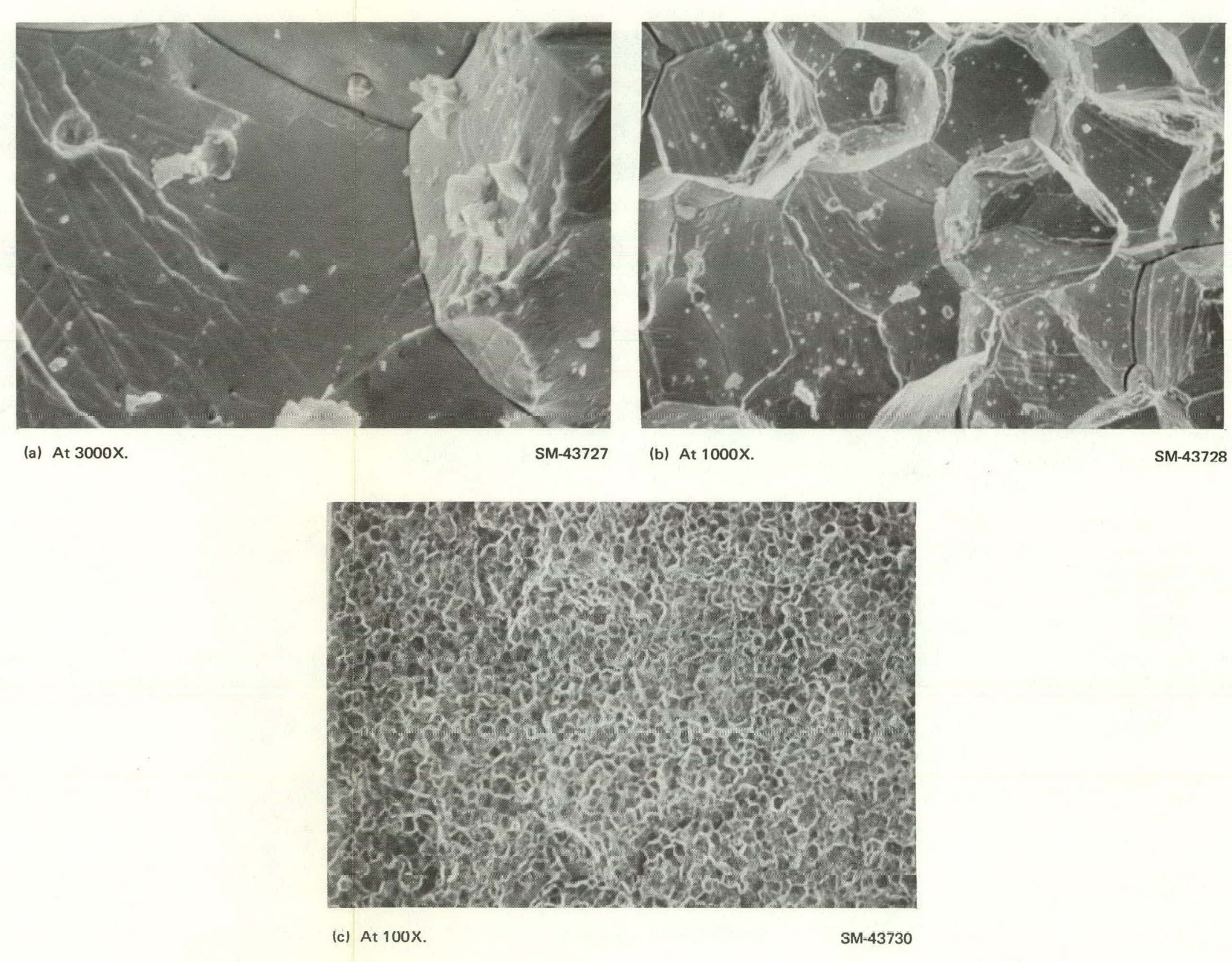

Figure A-27. SCANNING ELECTRON MICROGRAPH OF A STRESS.CORRoSION FRACTURE SURFACE OF URANIUM-10 WEIGHT PERCENT NIOBIUM. 


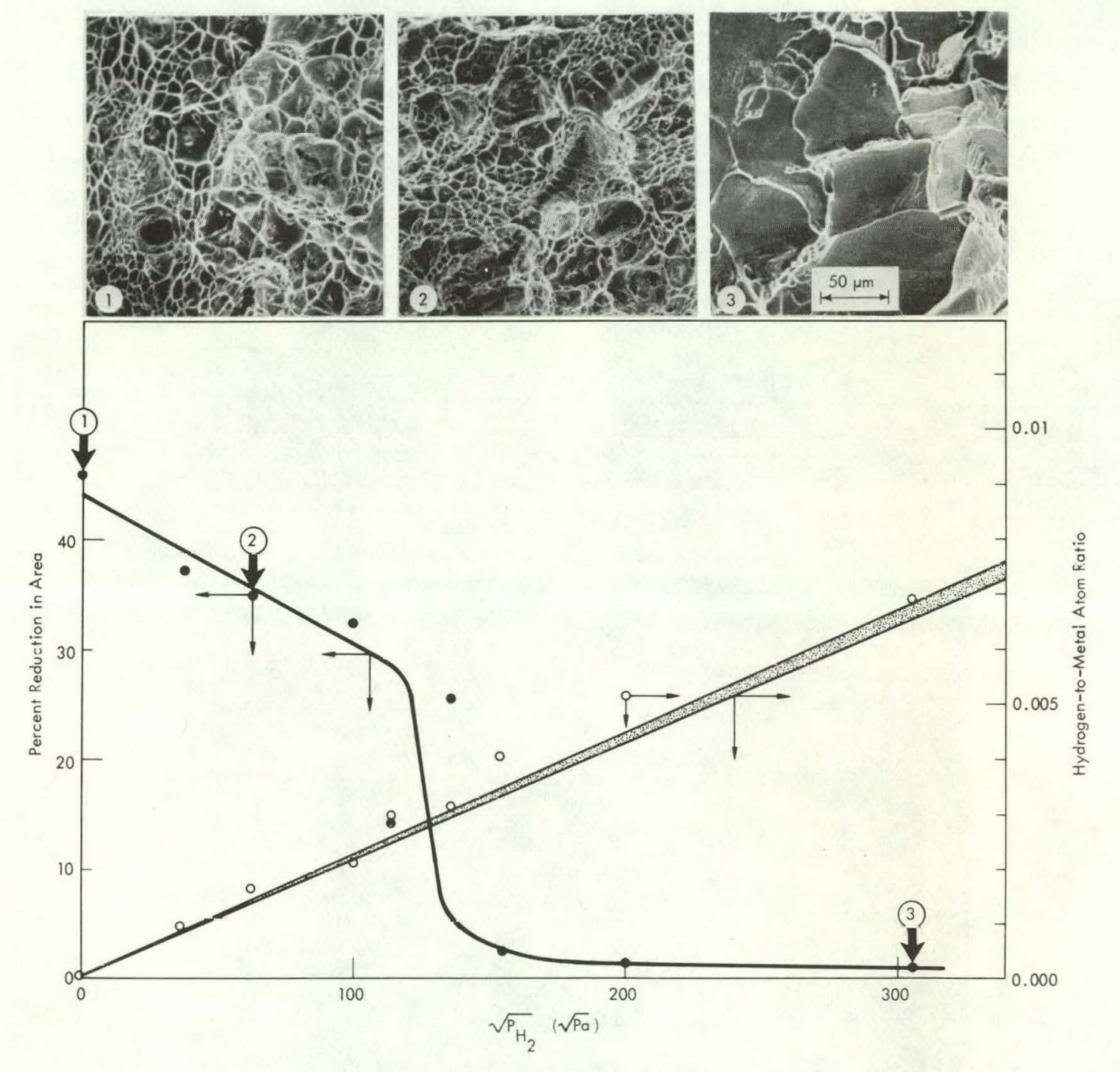

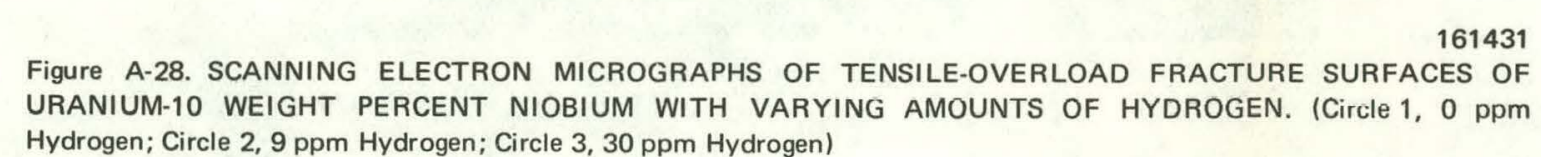
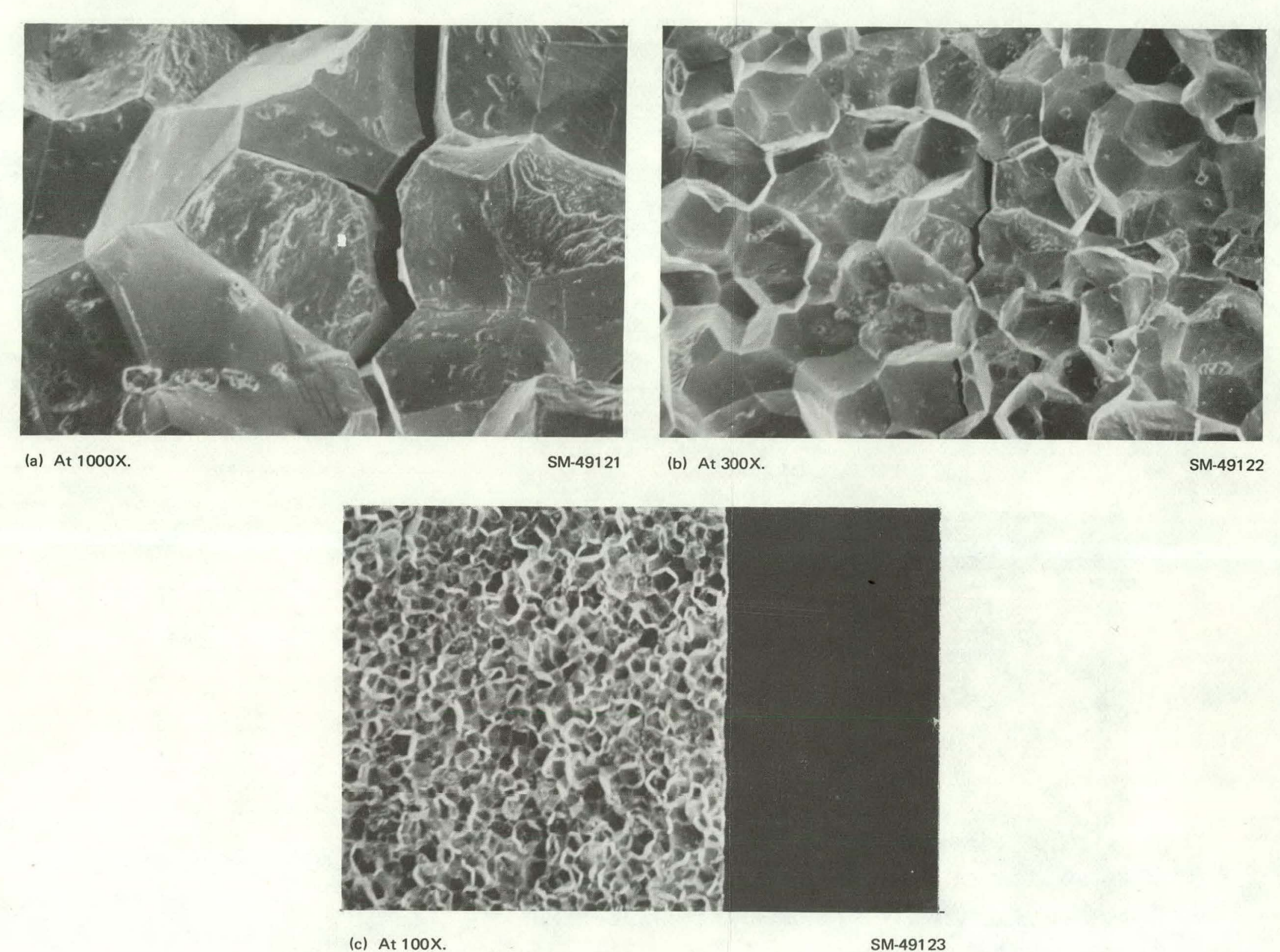

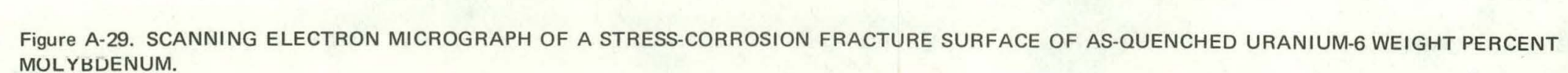



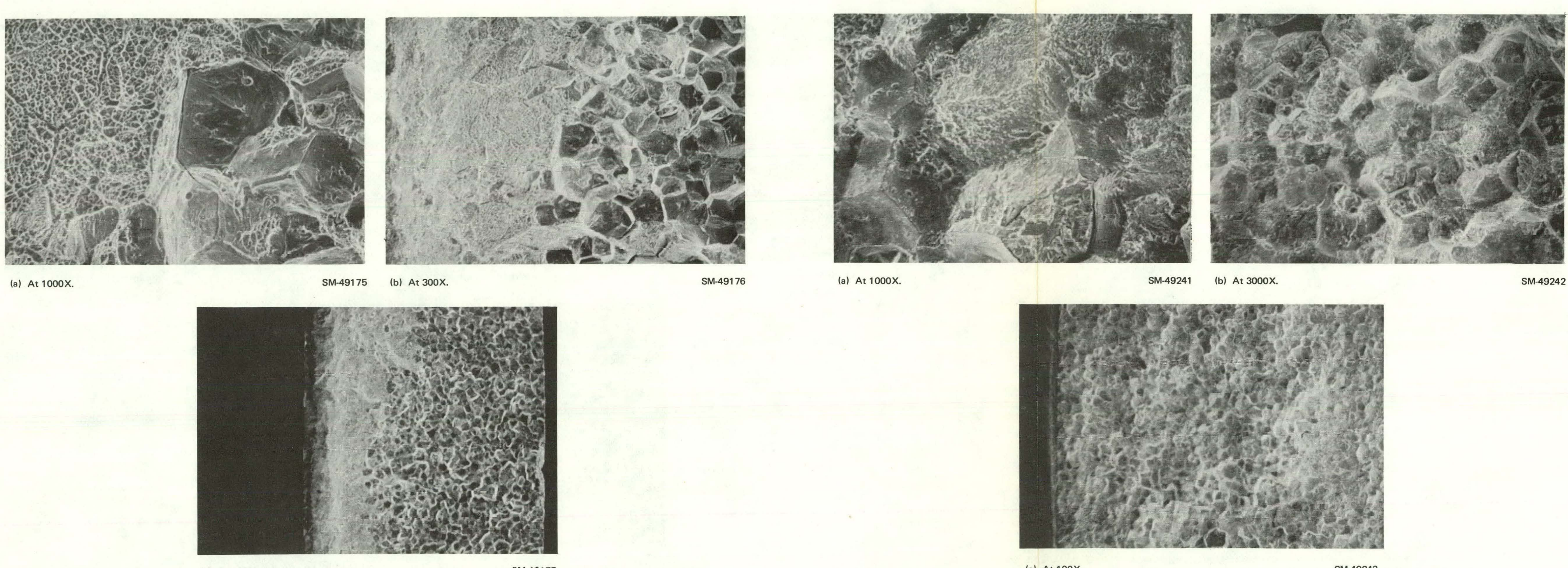

$\begin{array}{ll}\text { SM. } 49176 & \text { (a) At } 1000 x\end{array}$

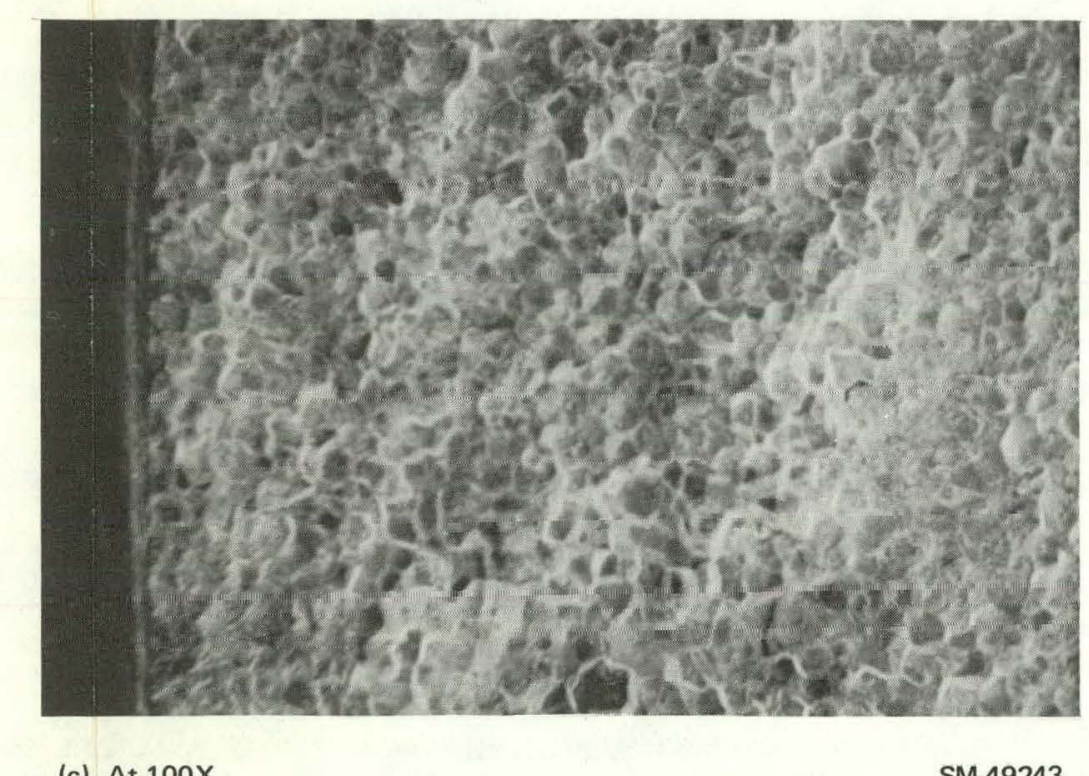
sh-49242 

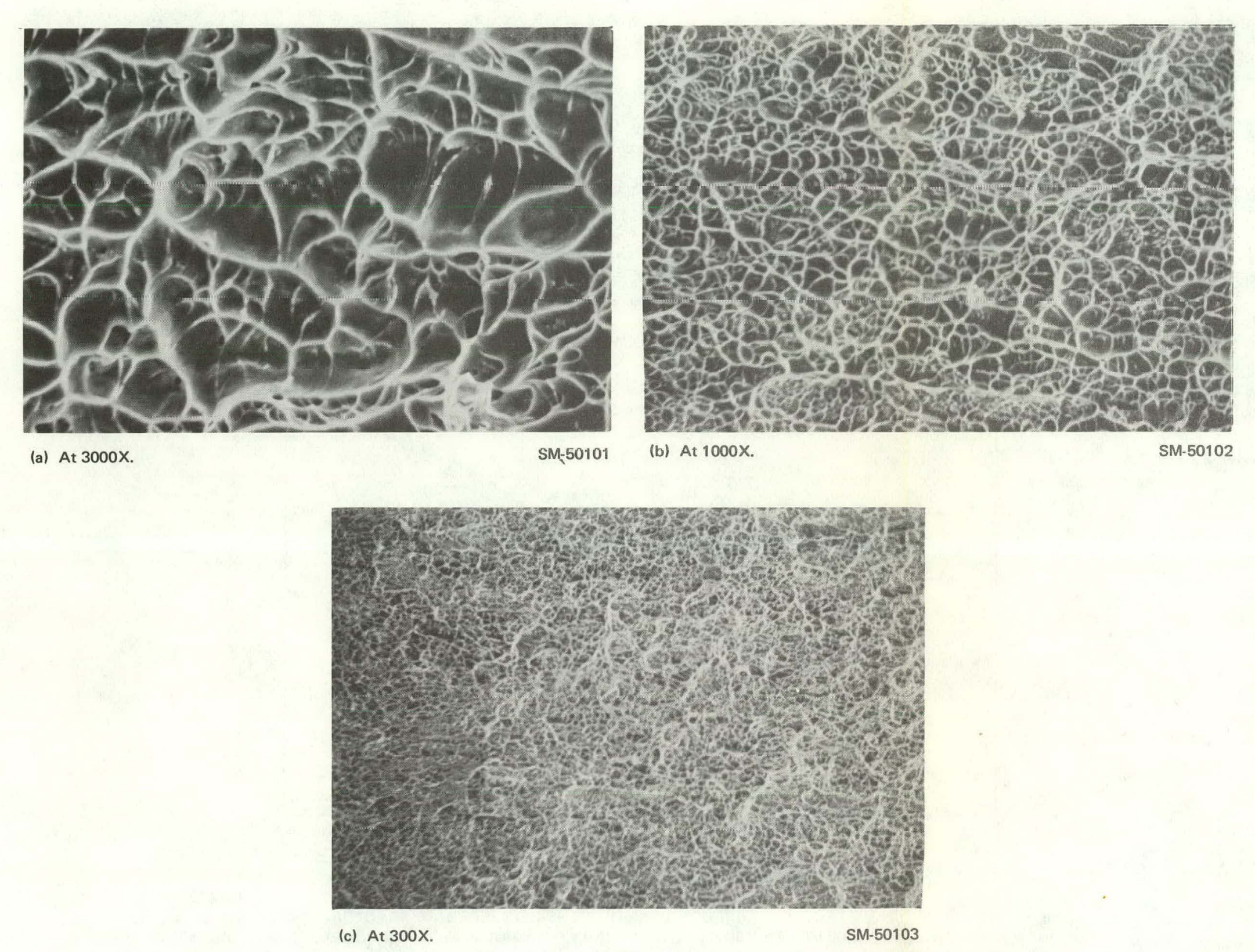

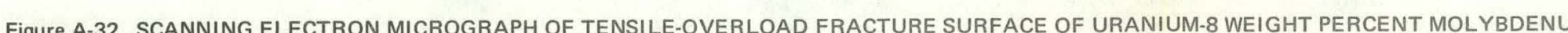
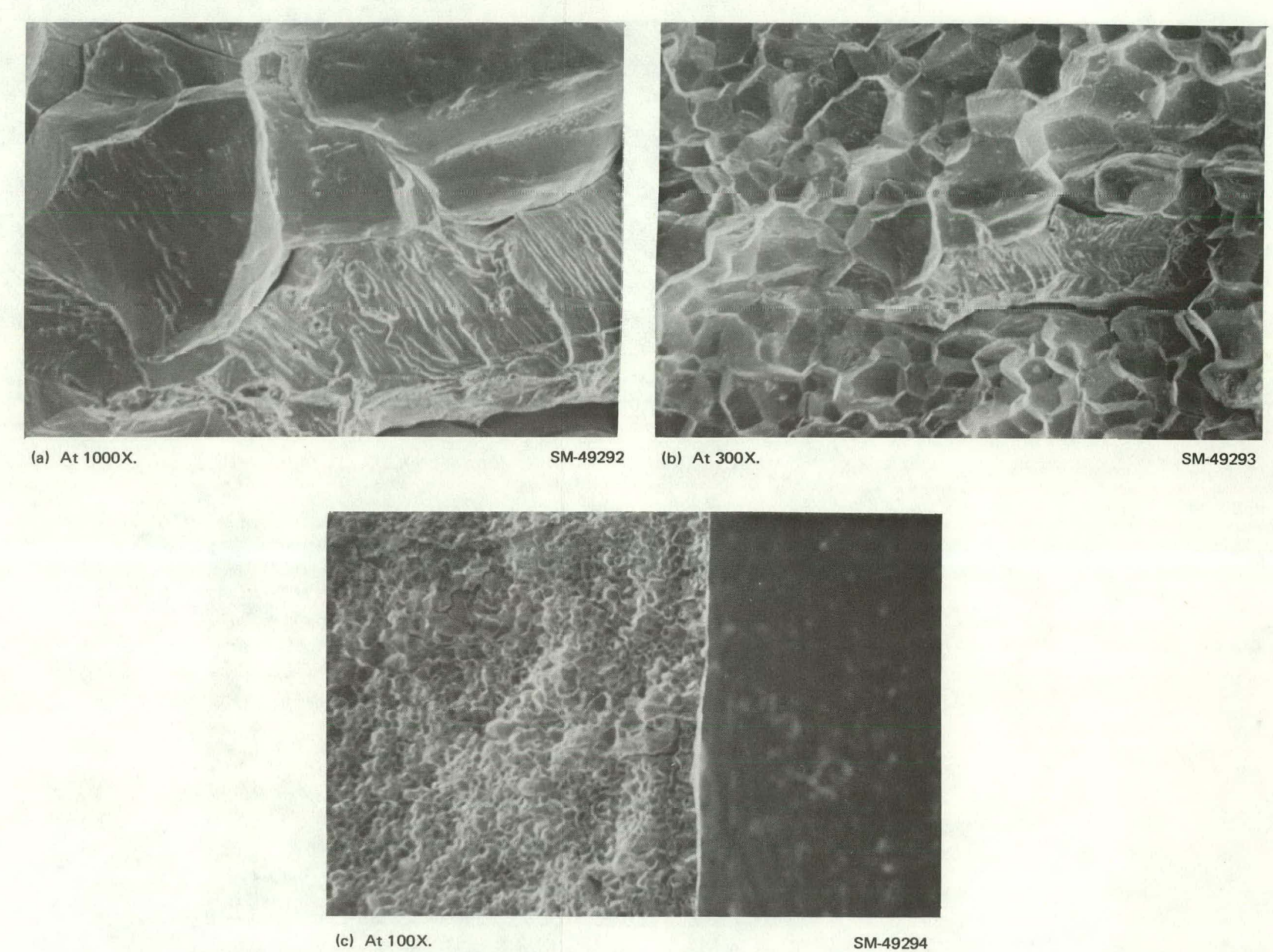

Figure A-33. SCA
MOLYBDENUM. 

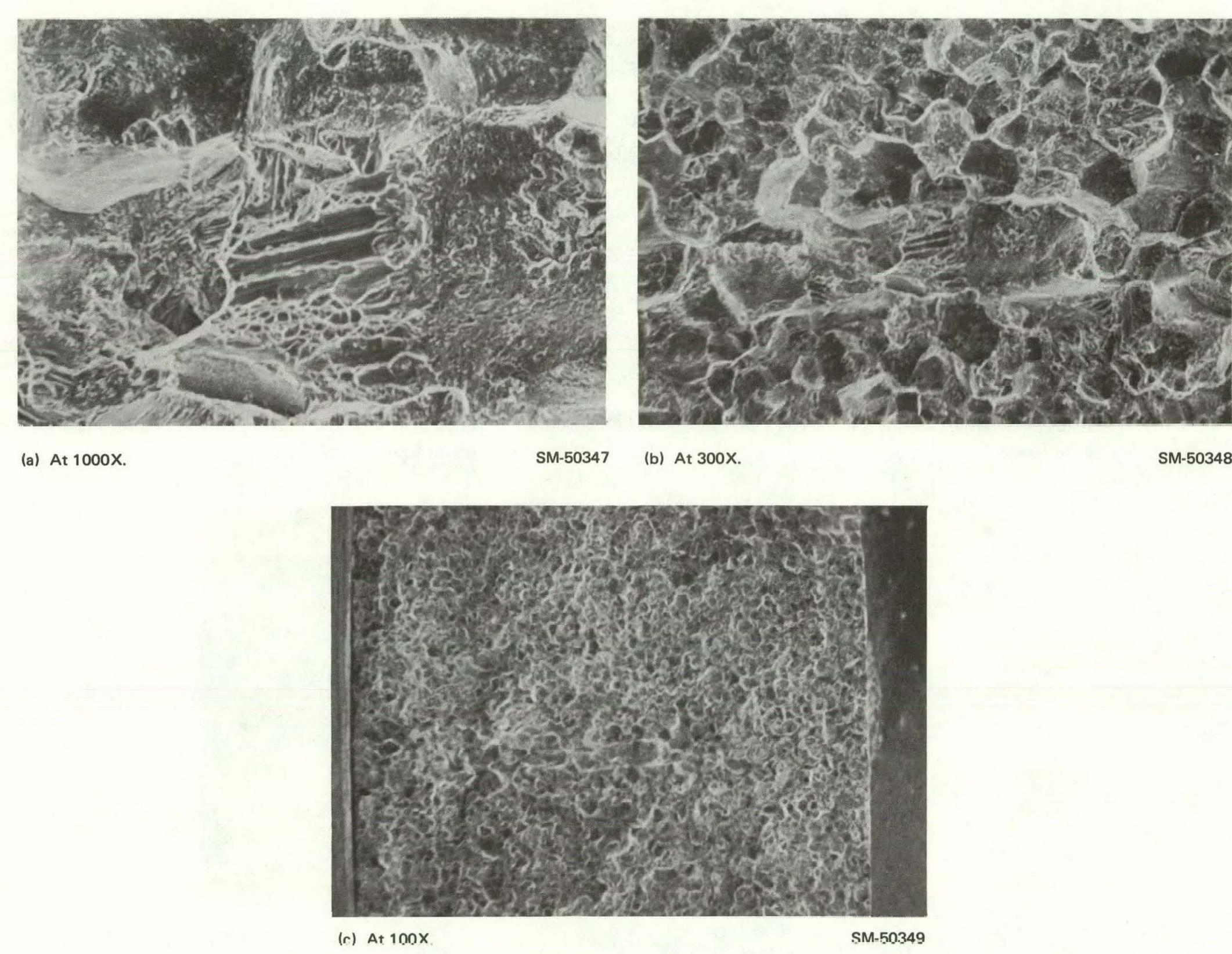

Figure A-34. SCANNING ELECTRON MICROGRAPH OF A STRESS.CORROSION FRACTURE SURFACE OF URANIUM-8 WEIGHT PERCENT MOLYBDENUM

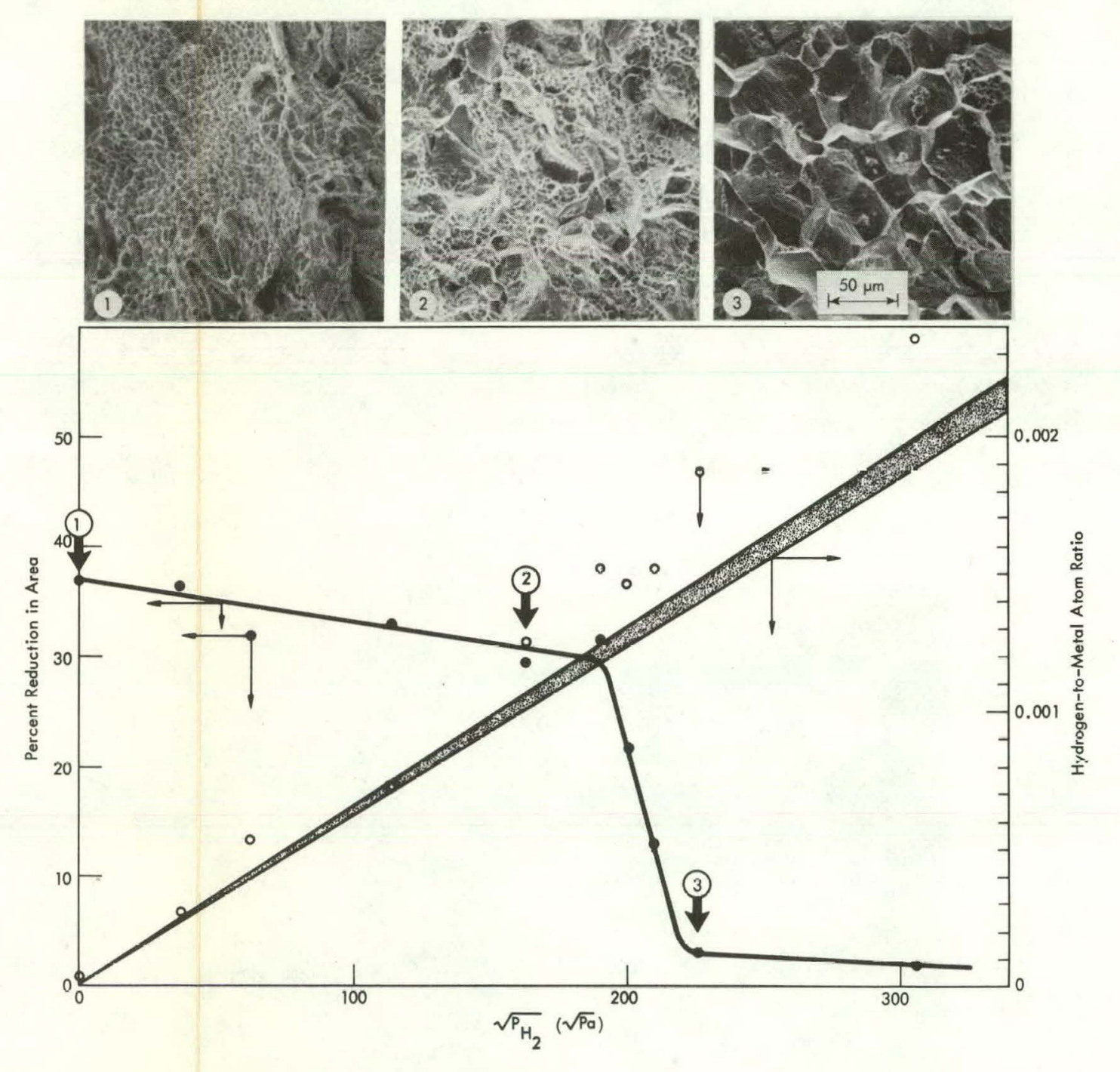

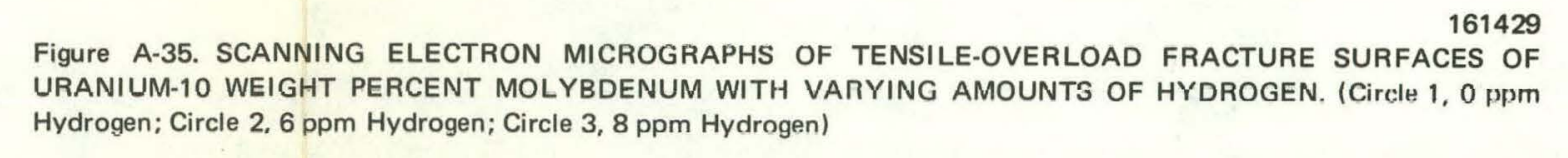



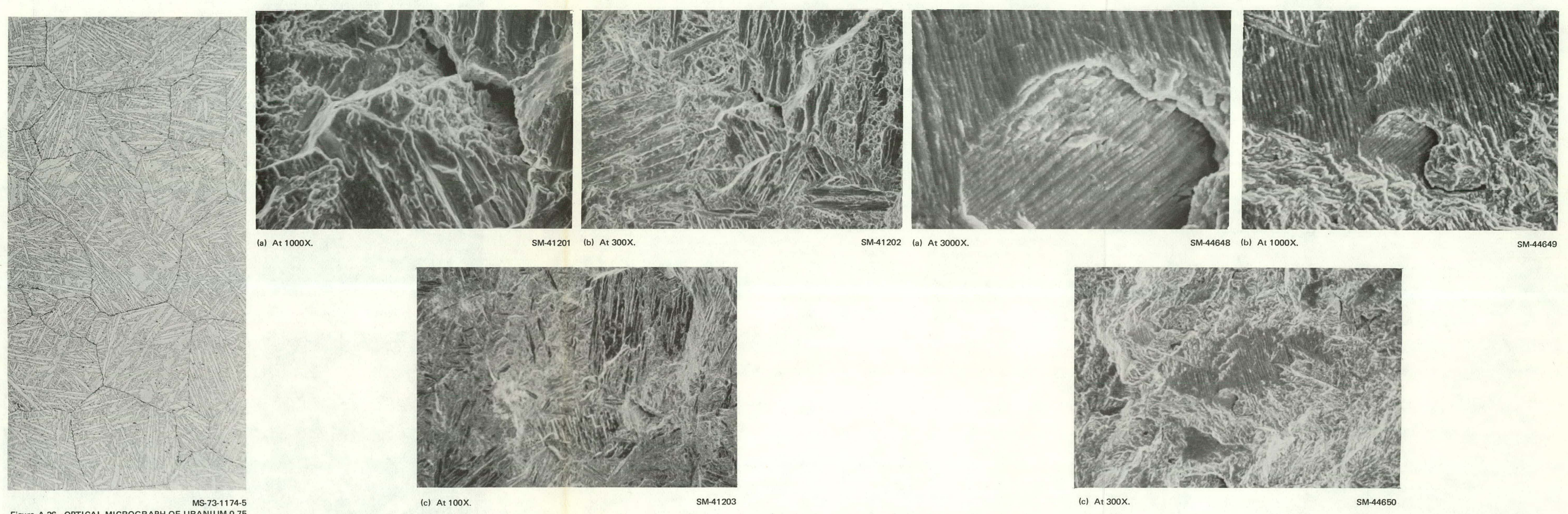

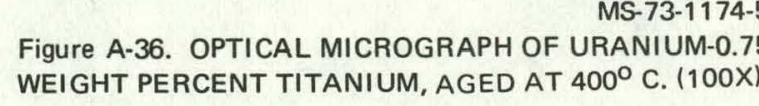

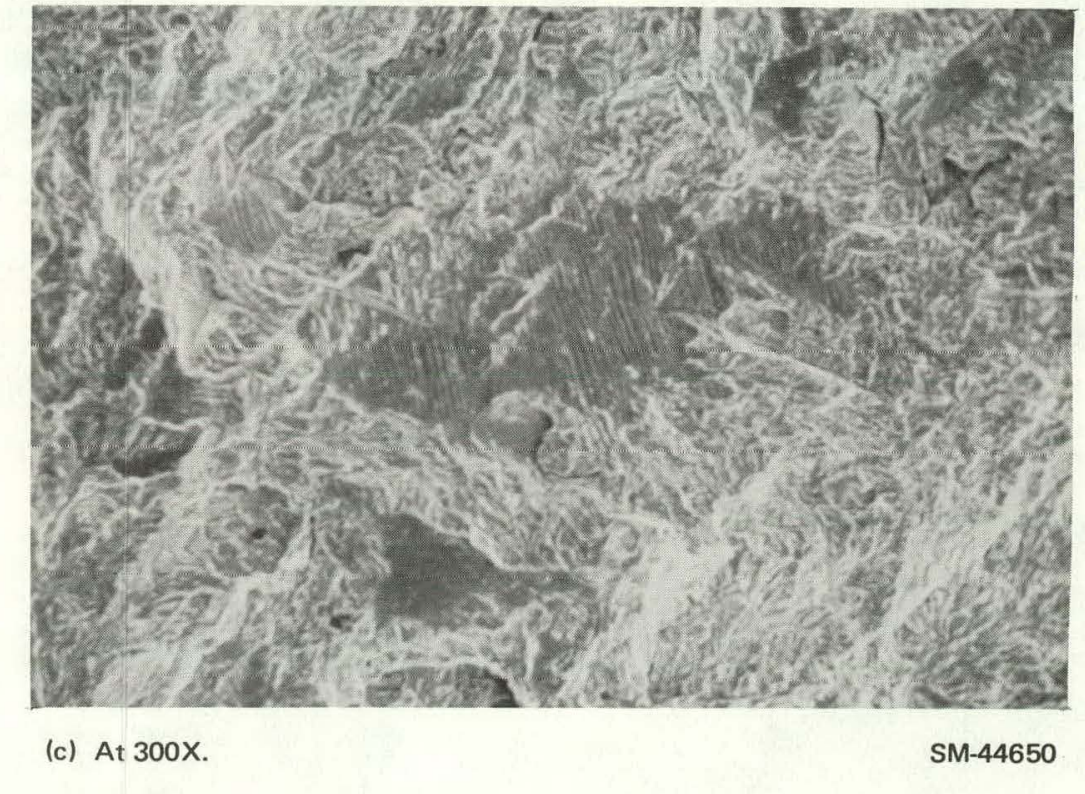

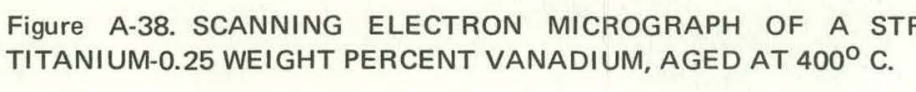




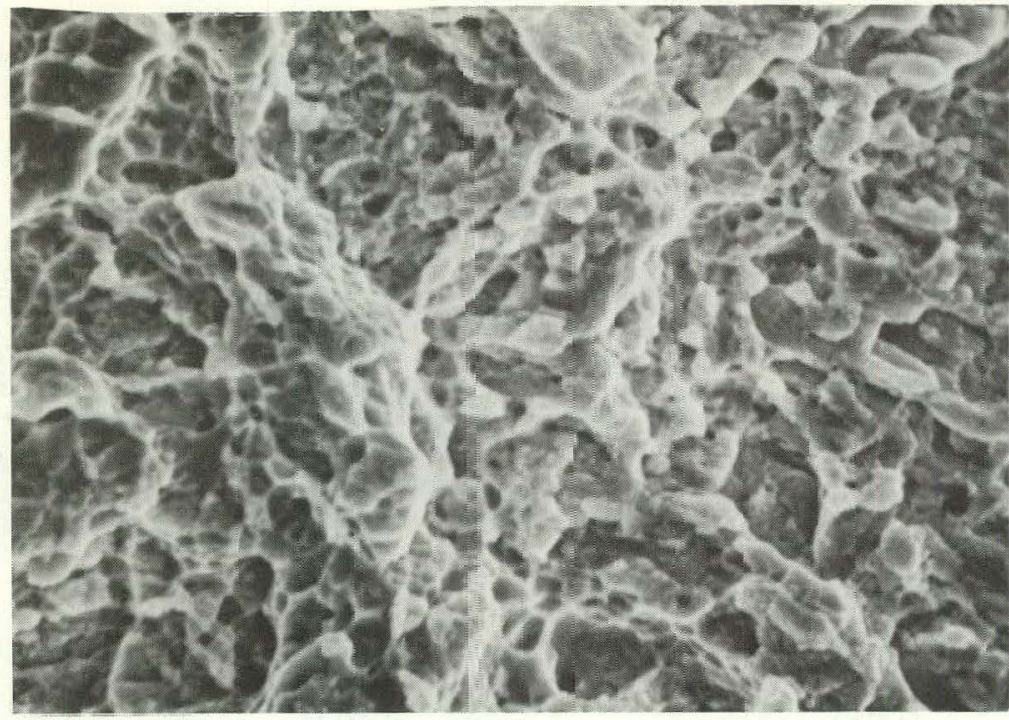

(a) At $3000 x$.

SM-44617

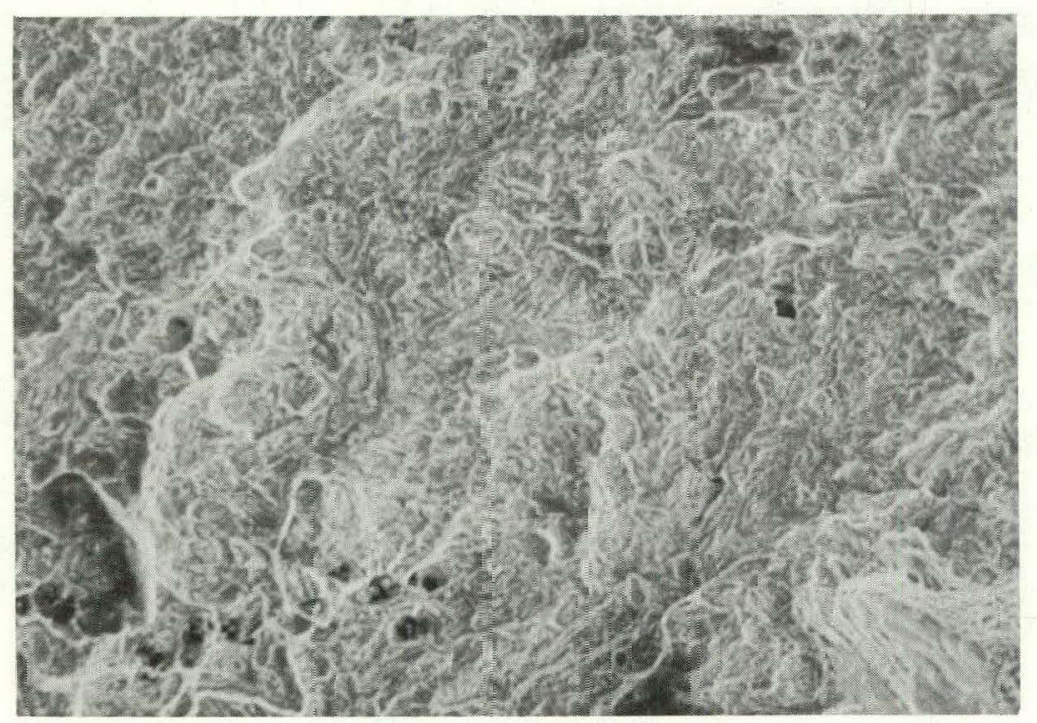

(c) At $300 x$.

SM-44619

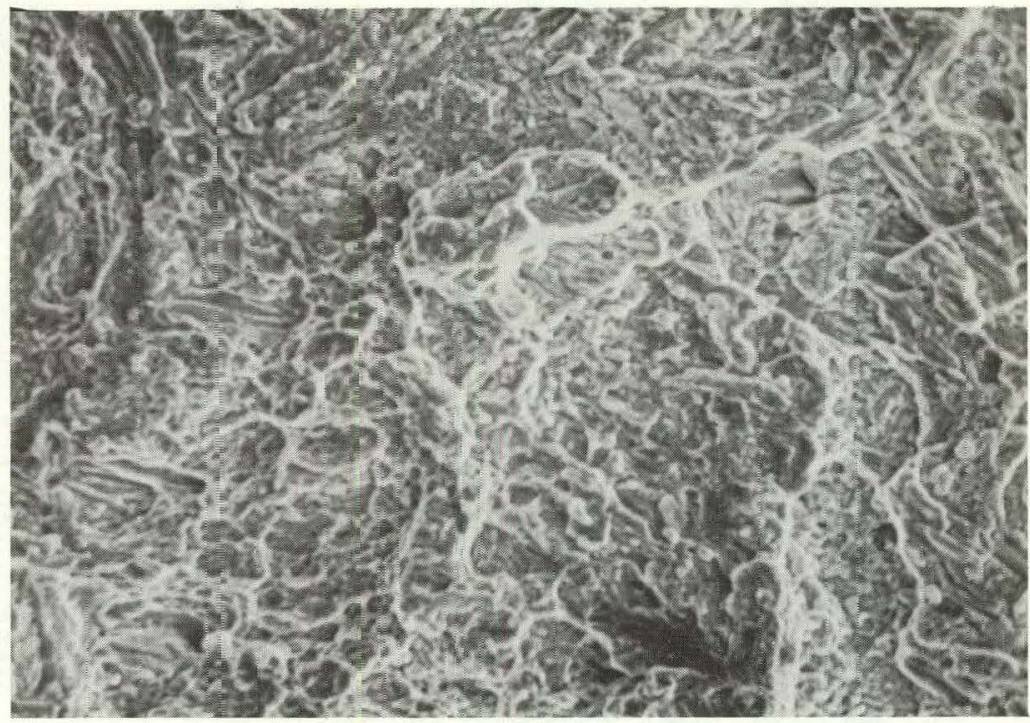

(b) At $1000 \mathrm{X}$.

SM-44618

Figure A-39. SCANNING =LECTRON MICROGRAPH OF A TENSILE-OVERLOAD FRACTURE SUFFACE OF URANIUM-0.75 WEIGHT PERCENT TITANIUM-0.25 WEIGHT PERCENT VANADIUM, AGED AT $400^{\circ} \mathrm{C}$ 


\section{Distribution}

\section{Aerospace Corporation}

Kendall, G.

Air Force Armaments Laboratory

Wilson, $L$.

\section{Air Force Materials Laboratory}

Inouye, S.

Battelle Memorial Institute - Columbus

Meyer, G.

Battelle-Pacific Northwest Laboratories

Kemper, $\mathrm{R}$.

Energy Research and Development

Administration - Oak Ridge

Hickman, H, D.

Leed, R. E.

Zachry. D. S., Jr

Lawrence Livermore Laboratory

Nelson, W. E.

Robbins, J. L.

Los Alamos Scientific Laboratory

Hockett, J. R.

Hoyt, H. C.

Sandstrom, D.

National Lead of Ohin

Levy, L. M.

Poulsen, C. E.

Oak Ridge Gaseous Diffusion Plant

Stief, S. S.

Wilcox, W. J., Jr

Oak Ridge National Laboratory

Brinkman, C. R.

Cathcart, J. V.

Martin. W. R.

McHargue, C. J.

Vandermeer, R. A.

Weir, J. R., Jr" 


\section{Oak Ridge Y-12 Plant}

Armstrong, R. C.

Bennett, R. K., Jr (5)

Bernander, N. K.

Dodson, W. H.

Fraser, R. J.

Jessen, N. C.

Johnson, D. H.

Keith, A.

Koger, J. W. (5)

Ludwig, R. L.

Masòn, D. L.

McElroy, B. D.

Mills, J. M., Jr

Phillips, L. R.

Poore, M. W.

Rowan, J. H.

Schreyer, J. M.

Smith, H. F.. Ir

Snyder, W. B.

Stoner, H. H.

Yagggi, W. J./Googinin, J. M.

$Y-12$ Central Files (5)

Y-12 Central Files (master copy)

$Y$-12 Central Files (route copy)

$Y-12$ Central Files $(Y-12 R C)$

\section{Picatinny Arsenal}

Hulbert, R.

\section{Rock Island Arsenal}

Johnson, L.

Rockwell International - Rocky Flats

Jackson, R. J.

Wiederecht, D. A.

\section{Sandia - Albuquerque}

Davis, M. J.

Ledman, J. L.

Maýnianio, N. J.

Rohde, R, W.
Sandia - Livermore

Adolphson, D. R.

Saxton, H. J.

Union Carbide Corporation -

New York

Winters, Charles

Union Carbide Corporation -

Parma Research Center

Chambers, W. E.

University of Temnessee -

College of Engineering

Stansbury, E. E.

US Army Ballistic Research Laboratories

Bloore, E. W.

Gillich, W.

US Army Materials and Mechanics Research Center

Larsen, $F$.

\section{US Naval Weapons Laboratory}

Cruwe, R.

Fishman, S. 